Acadiensis

Journal of the History of the Atlantic Region

Revue d'histoire de la région Atlantique

\title{
The "Morals of Genealogy": Liberal Settler Colonialism, the Nova Scotia Archives, and the North American Ancestor-Hunters, 1890-1980
}

\section{Ian McKay}

Volume 48, numéro 2, automne 2019

URI : https://id.erudit.org/iderudit/1067767ar

Aller au sommaire du numéro

\section{Éditeur(s)}

Department of History at the University of New Brunswick

ISSN

0044-5851 (imprimé)

1712-7432 (numérique)

Découvrir la revue

Citer cet article

McKay, I. (2019). The "Morals of Genealogy": Liberal Settler Colonialism, the Nova Scotia Archives, and the North American Ancestor-Hunters, 1890-1980. Acadiensis, 48(2), 43-89.
Résumé de l'article

La généalogie occupait une place importante dans la culture de la Nouvelle-Écosse des années 1890 aux années 1970. Pourtant, lorsque D.C. Harvey, l'archiviste provincial à compter de 1931, a défini les principaux objectifs des Archives publiques de la Nouvelle-Écosse, il a exclu la recherche généalogique des objectifs fondamentaux de ce "laboratoire historique ". Il menait une bataille perdue d'avance. Que cela lui ait plu ou non, l'institution qu'il dirigeait faisait partie d'un réseau mnémonique transnational à l'intérieur duquel les approches généalogiques devenaient de plus en plus influentes, et d'une province dont l'élite coloniale blanche avait des liens profonds avec la Nouvelle-Angleterre, l'épicentre de la généalogie populaire aux États-Unis. 


\title{
The "Morals of Genealogy": Liberal Settler Colonialism, the Nova Scotia Archives, and the North American Ancestor-Hunters, 1890-1980
}

\author{
IAN MCKAY
}

La généalogie occupait une place importante dans la culture de la Nouvelle-Écosse des années 1890 aux années 1970. Pourtant, lorsque D.C. Harvey, l'archiviste provincial à compter de 1931, a défini les principaux objectifs des Archives publiques de la Nouvelle-Écosse, il a exclu la recherche généalogique des objectifs fondamentaux de ce " laboratoire historique ». II menait une bataille perdue d'avance. Que cela lui ait plu ou non, l'institution qu'il dirigeait faisait partie d'un réseau mnémonique transnational à l'intérieur duquel les approches généalogiques devenaient de plus en plus influentes, et d'une province dont l'élite coloniale blanche avait des liens profonds avec la NouvelleAngleterre, l'épicentre de la généalogie populaire aux États-Unis.

Genealogy loomed large in the culture of Nova Scotia from the 1890s to the 1970s, yet when D.C. Harvey, the provincial archivist after 1931, defined the key purposes of the Public Archives of Nova Scotia, he excluded genealogical research from the core objectives of this "historical laboratory." He was fighting a losing battle. Like it or not, the institution he headed operated as part of a transnational mnemonic network within which genealogical approaches were becoming more influential and within a province whose White colonial elite had deep connections with New England - the epicentre of popular genealogy in the United States.

They came with conquering vision, but with words direct and cold,

To found a race of noblemen, fine-fibred sturdy, bold, -

A race of earnest people, who in mellower times shall reach

The heights of wider knowledge, and the plains of gentler speech.

- A.W. Eaton, History of Kings County, Nova Scotia

"HALF THE POPULATION OF THE UNITED STATES AND EASTERN CANADA are badgering me about genealogy," D.C. Harvey (1886-1966), the provincial archivist of Nova Scotia, complained to his good friend and

1 A.W. Eaton, The History of Kings County Nova Scotia, Heart of the Acadian Land, Giving a Sketch of the French and their Expulsion; and a History of the New England Planters who Came in Their Stead, with Many Cenealogies, 1604-1910 (Salem, MA: Salem Press Company, 1910), 395. My thanks to the three perceptive and anonymous reviewers of this article for Acadiensis, as well as my fellow panellists and the audience members at the Canadian Historical Association panel in Regina in 2018 where the paper upon which it is based was first presented.

Ian McKay, "The 'Morals of Genealogy': Liberal Settler Colonialism, the Nova Scotia Archives, and the North American Ancestor-Hunters, 1890-1980," Acadiensis 48, no. 1 (Autumn/ automne 2019): 43-89. 
eminent historian J.B. Brebner in 1934. "In the midst of it all I am trying to retain my sanity and to get the occasional sleep though denied exercise and frivolity." The following year he explained his "depression" in terms of all the competing demands upon his time, among them the pressures of being a "source of information for half-baked genealogists." Phyllis Blakeley (19221986), who joined the staff of the Public Archives of Nova Scotia (PANS) in 1946, exclaimed in 1951: "I don't mind regular researchers, but so many of the people I have had this month are ancestor hunters who barely know their grandfather's name and yet are certain their family is famous, and get annoyed when you can't furnish a complete history in ten seconds." A year later, in 1952, she wrote "I don't care for genealogy - in fact it bores me," although she was also pondering joining a genealogical committee organized by the Nova Scotia Historical Society (NSHS). ${ }^{5}$ Speaking in 1985 to a dinner given in honour of her pending retirement, she estimated that, over her career of four decades at the archives, about 50 per cent of her interactions and letters had involved the "ancestor-hunters" - which worked out to be around 1,200 genealogical enquiries in 1983 alone. $^{6}$

Research into the history of the archives in North America has been ongoing since the 1960s, and over time a close focus on principles and debates internal to the archival community has been supplemented by more wideranging historical appraisals of archives' wider social and intellectual history. If in some respects the Nova Scotia evidence speaks eloquently to wider international theoretical debates, because it pertains to the first state archives in Canada, in others it must be carefully contextualized in its local context since, in many respects, despite its official name, the leaders of the Archives down to the 1960 s indicated only a partial awareness of the principles of

2 Throughout this paper the "Archives" refers to the Public Archives of Nova Scotia (PANS, fd. 1931), which later in the 20th century went by the name of Nova Scotia Archives and Record Management and, after 2010, became the Nova Scotia Archives. I also use the term to refer to the Nova Scotia branch of the Dominion Archives because this office and much of its collection was subsumed by PANS in 1931. Unless otherwise indicated, "the Archivist" refers to those leading the Archives - Alvin F. MacDonald, head of the Dominion Branch through much of the 1920s, D.C. Harvey of PANS from 1931 to 1956, and C.B. Fergusson after 1956.

3 D.C. Harvey to J. Barlet Brebner, 14 February 1935, RG 53, vol. 5 (1935), PANS.

4 Phyllis Blakeley to Shirley [Blakeley], 31 August 1931 (with an internal letter of 3 August 1951), Phyllis Blakeley Fonds, MG1, vol. 3045, file 14, PANS.

5 Phyllis Blakeley to Shirley [Blakeley], 1 November 1951 (with internal letter of 5 November), Phyllis Blakeley Fonds, MG1, vol. 3045, PANS.

6 Phyllis R. Blakeley, "Forty Years at the Archives" (1st Draft, November 1985), MG1, vol. 3124, file 2, PANS; Remarks by Dr. Blakeley, 30 March 1985, MG 1, vols. 3052-3053, PANS; Phyllis Blakeley, Tally Sheet, 1983, MC1, vol. 3048, file no. 4, PANS 
archival science. Founded in the 1850 in large part as an exercise in damage control in response to Longfellow's depiction of cruel Britons unsettling tranquil Acadians in his epic poem Evangeline, ${ }^{7}$ the institution functioned for the most part more as a general research library, research centre, and nexus for local historians than as a specialized archives preoccupied with such classic issues as provenance and original order or the newer ones created by the realities of modern record management. ${ }^{8}$ This article emerges from a general project of situating this archives within a general framework of the emergence of settler-colonial liberalism in Canada as a philosophy of life as well as a mode of governance, and it is particularly interested in discerning how such seemingly abstract topics might be related to the everyday workings of this one local institution. ${ }^{9}$ The gradual rise of genealogy to a hegemonic and profitable

7 See B.C. Cuthbertson, "Thomas Beamish Akins: British North America's Pioneer Archivist," Acadiensis 12, no. 1 (Autumn 1977): 86-102.

8 The history of archival ideas has generated a considerable number of books and articles since the 1960s. For general appraisals, see Richard C. Berner, Archival Theory and Practice in the United States: A Historical Analysis (Seattle and London: University of Washington Press, 1983); Richard J. Cox, American Archival Analysis: The Recent Development of the Archival Profession in the United States (Metuchen, NJ: Scarecrow Press, 1990); and Cox, Closing an Era: Historical Perspectives on Modern Archives and Records Management (Westport, CT and London: Greenwood Press, 2000). For elegant and succinct overviews from a Canadian perspective, see especially Terry Cook, "What is Past is Prologue: A History of Archival Ideas Since 1898, and the Future Paradigm Shift," Archivaria 43 (Spring 1997): 17-63, and Cook, "The Archives is a Foreign Country: Historians, Archivists, and the Changing Archival Landscape," Canadian Historical Review 90, no. 3 (September 2009): 497-534; in general, see Barbara L. Craig, ed., The Archival Imagination: Essays in Honour of Hugh A. Taylor (Ottawa: Association of Canadian Archivists, 1992). For an important intervention distinguishing between archival practice and state records management, see George Bolotenko, "Historians and Archivist: Keepers of the Well," Archivaria 16 (Summer 1983): 5-25 and Bolotenko, "Instant Professionalism: To the Shiny New Men of the Future," Archivaria 20 (Summer 1985): 149-57. For appraisals of the history of PANS from its archivists' own perspectives, see D.C. Harvey, "Archives and Historical Research in the Maritimes," Dalhousie Review 23 (1943-44): 193-205; C. Bruce Fergusson, The Public Archives of Nova Scotia (Halifax: Public Archives of Nova Scotia, Bulletin No. 19, 1963); Hugh A. Taylor, "Archives in Great Britain and Canada - Impressions of an Immigrant," Canadian Archivist 1 (1969): 22-3; Taylor, "The Discipline of History and the Education of the Archivist," American Archivist 40, no. 4 (October 1977): 395-402; and Phyllis Blakeley, "Forty Years at the Archives" (paper read to the Royal Nova Scotia Historical Society, 4 April 1986), in MG1, vol. 3124, PANS. For other important works on PANS, see in particular Donald MacLeod, "Our Man in the Maritimes: 'Down East' with the Public Archives of Canada," Archivaria 17 (Winter 1983-84): 86105 and Robin Bates, "Writing for a Golden Age: James Stuart Martell and the Public Archives of Nova Scotia" (MA thesis in history, Queen's University, 2004).

9 The present article is one of a series of explorations by the author of the cultural history of the Public Archives of Nova Scotia that place special emphasis on their role in legitimizing liberal colonialism. For some of the others, see "Cashing In On Antiquity: Tourism and the Uses of History in Nova Scotia, 1890-1960," chap. 14 in Settling and Unsettling Memories: Essays in Canadian Public History, ed. Nicole Neatby and Peter Hodgins (University of Toronto Press, 2012), 573-627; "Imagining a Liberal Enlightenment: D.C. Harvey and a 'Laboratory for History' for Nova Scotia," Journal of the Royal Nova Scotia Historical Society 16 (2013): 154-80; "Margaret Ells Russell, Women Strike for Peace, and the Global Politics of 'Intelligent Compassion,' 1961-1965," in Lara Campbell, Michael Dawson, and Catherine Gidney, eds., Worth Fighting For: Canada's Tradition of War Resistance (Toronto: Between the Lines, 2015), 119-32; "Liberty, 
position among approaches to the past can be interpreted as one example of liberal possessive individualism, because it has generally entailed the pursuit of particular individuals in the past (usually males carrying the "family name") on behalf of particular individuals in the present (often to enhance claims to social status).

But what is genealogy? Like "history," "genealogy" is a term that has the misfortune of designating both an object of inquiry ("a line of descent, a string of ancestors, a list of members of one family") and the intellectual practices involved in that inquiry. It is "the science of family relationships and lineages or more broadly ... a personal interest in one's forebears." ${ }^{10}$ Such helpful pointers from scholars Caroline-Isabelle Caron and François Weil suggest both the breadth and intricacy of the term, and a similar complexity haunts the "genealogist" - i.e., those who pursue such inquiries. They might range from a humble person entering names in a family Bible for the edification of his or her immediate kin all the way through to a NASDAQ-listed multinational corporation marketing access to a multi-billion-strong database. Motivations behind constructing genealogical accounts might similarly vary, ranging from the personal (the avoidance of consanguinity) to the mercenary (the acquisition of land) and to the spiritual (as in the Mormons' drive to construct, in Don Akenson's words, "the master narrative into which each one of us fits"). ${ }^{11}$

In the "genealogy of genealogy" I present here, genealogy is interpreted in a broad sense to encompass all efforts to capture the past via a focus on lines of biological descent from a real or imagined ancestor or ancestors to a person or persons in the present. Those pursuing such efforts can be placed in five categories: (1) amateur ancestor-hunters, often working to fill in the blanks of their family trees or merely striving to pass family tales on to the

Equality and Tourism: D.C. Harvey, Prince Edward Island, and the Power of Tourism/History, 1931-1956," Histoire sociale / Social History 49, no. 99 (Juin/June 2016): 265-89; "The Archivist as Activist: J.S. Martell of Nova Scotia" (presentation to the Canadian Historical Association, Ottawa, June 2015); "D.C. Harvey, Pioneer Equality, and a Canadian Vision of Settler Colonialism, 1911-1936" (presentation to the Canadian Historical Association, Calgary, June 2016); and "Public History, Disputatious Antiquarians, and Awkward Ancestors: D.C. Harvey and Nova Scotia's Acadians, 1936-1962" (presentation to the Canadian Historical Association, Toronto, June 2017).

10 Caroline-Isabelle Caron, Se créer des ancêtres: un parcours généalogique nord-américain $X I X^{e}-X X^{e}$ siècles (Sillery, QC: Les éditions du Septentrion, 2006), 11 (my translation); François Weil, Family Trees: A History of Genealogy in America (Cambridge, MA and London: Harvard University Press, 2013), 2. See also Caroline-Isabelle Caron, "Se créer des ancêtres. Les écrits historiques et généalogiques des de Forest et des Forest d'Amérique du Nord, 19e et 20e siècles" (PhD diss. in history, McGill University, 2001).

11 Donald Harman Akenson, Some Family: The Mormons and How Humanity Keeps Track of Itself (Montreal and Kingston: McGill-Queen's University Press, 2007), 7. Elsewhere Akenson himself acclaims genealogy as "the most fundamental form of humanity's collective history" (16). 
next generation; (2) amateurs who devote themselves to constructing ambitious multi-generational lists pertaining to their ancestors or to the settlers of entire areas because they wanted to encourage reverence for their supposed traditions; (3) actual or aspiring members of organizations through which particular family identities were stabilized and preserved in a broad range of filiopietistic symbols, activities, and publications; (4) genealogically oriented history writers who emphasize, whether in whole or in part, the seminal cultural importance of the "stock" of particular founding families and groups; and finally (5) professionals and organizations profiting from the sale of genealogical data and findings to other people.

Such distinctions are helpful, because they clarify what we mean when we talk about the rise or decline of "genealogy." To an important extent anybody born within a culture shaped by the major monotheistic religions is a "genealogist" to some degree, shaped by authoritative stories of exalted people long ago doing important things one should bear in mind in one's own life. Stories about parents and relatives, family records - old Bibles, tombstones, burial grounds - and sacred landscapes are all "genealogical" in this very general sense, and form the widely shared substrate of sentiments about the past to which amateur family tree hunters devote some of their time. People in category (2) go beyond this common, garden interest in their own family's traditions to more ambitious interpretive systems, often requiring many hours to complete. Doing so sometimes brings them into category (3), wherein such systems are integrated into broader social and cultural networks of the likeminded, and on occasion into category (4), where bold claims are made for history in general on the basis of such interpretations. Finally, those in (5) are the furthest removed from the humble compiler of a list in a family Bible insofar as they are promoters, not of a specific genealogy, but of a trade devoted to propagating and profiting from this particular mode of historical inquiry.

Many, perhaps most, Nova Scotians of all descriptions have been "genealogists" in the first sense; a small minority were attracted by category (2) or (3) genealogical projects from the 1920 s to the 196os. Yet, as residents of a province strongly influenced by New England, Nova Scotians were also increasingly brought into direct contact with genealogists from outside the province for whom genealogy was a pursuit encompassing all five categories.

Claims that Nova Scotians have always oriented their understandings of the past to histories of their own or other families are overdrawn. Indeed, in PANS, the province's premier historical institution from the 1930s to the 1970s, such 
genealogical frameworks of understanding were often resisted on progressive grounds. There were other scientifically and morally superior ways of grasping the past, such historical progressives argued, than through adopting a genealogical lens. Sometimes belittled as the reactions of dyed-in-the-wool elitist archivists rejecting the modest efforts of average people to understand the past, such critiques of genealogy were more complicated than that. In many respects they also proceeded on the assumption that genealogy, when it became something more than a personal quest for family information, represented an intellectual dead end and, when it operated in ways that hampered scholars' capacity to arrive at well-founded historical generalizations, an affront to hardworking, honest historians. With apologies to Nietzsche, one could even say that such archivists took umbrage at the "morals of genealogy."

\section{The New England template}

In a useful and far-ranging survey of the American experience, François Weil suggests that genealogy in the US passed through four stages: from an 18thcentury obsession with pedigree through to a post-Revolutionary republican quest of heroic pioneers to the superiority-seeking scientific racism from the 1860 s to the 1950s, culminating in far more democratic patterns after the 1960 . Many mid-19th century and fin-de-siècle elite Americans remained obsessed with "aristocracy, lineage, and hereditary status," a blue-blood sensibility Weil associates particularly with major Atlantic port cities, the Hudson Valley, and the South. And he also underlines the extent to which a more emphatically racialized practice of genealogy after the 1860 s, culminating in a new "science" of eugenic genealogy, allowed some Americans hitherto reluctant to publicize their distinguished bloodlines to broadcast such supposed claims to social superiority, a change exemplified by the 1908 publication of Burke's Prominent Families of the United States. ${ }^{12}$ Such genealogies contributed powerfully to a version of American nationalism that was "more vocal, exclusive, and genealogically minded than ever," as the nation came to be imagined as one great extended family. Indications of this shift to a more racialized genealogical culture included the rise of patriotic-hereditary organizations, such as the Society of Sons of Revolutionary Sires, the Sons of the Revolution, and the Daughters of the American Revolution (DAR), the latter of which proudly stood

12 Arthur Meredyth Burke, The Prominent Families of the United States of America (London: Sackville Press, 1908). 
for the "purity of our Caucasian blood." Throughout this period of racialized genealogy, one found a "conflation of race, heredity, and nationalism." ${ }^{13}$

Yet, as Weil concedes, these stages unfolded unevenly across the country. Many in the Atlantic coastal cities maintained a preoccupation with noble lineage and hereditary exclusiveness well into the 20 th century and even beyond; there one found an enduring preoccupation with lineage and status. As Gail R. Redmann explains, 19th-century Americans "used genealogies to distinguish themselves from the new wave of immigrants, many of whom were from eastern and southern Europe." ${ }^{14}$ And one place where this was of particular significance was New England, where from the 1890 s to the $1940 \mathrm{OS}$ one found the flowering of a full-fledged cult of the Mayflower and a sustained effort to develop the Huguenots as the founders of America (sometimes with an emphasis on their supposed connection to European nobility).

Jean O'Brien notes that southern New England "produced an enormous body of literature in the nineteenth century. It dominated this culture of print, obsessed over its self-fashioned providential history, and defined itself as the cradle of the nation and seat of cultural power." ${ }^{\prime 5}$ John Farmer's Genealogical Register of the First Settlers of New England (1829) sought to democratize this genealogical genre by opening it up to the ordinary citizen. ${ }^{16}$ For François Weil, this 352-page tome, registering "the names of the large portion of the First Settlers, of the most prominent, as well as the more humble," transformed "the practice of genealogy in the United States." It meant not only that ordinary citizens found a measure of genealogical attention but that they started demanding different and more critical standards of evidence: "tradition" and "family lore" no longer sufficed. ${ }^{17}$ In New England colonial culture, "thousands of family Bible pages ... torn from their original books, now reside in New England libraries and provide indispensable information for the identification of their former owners' families," writes John Schutz. They often gave rise, at the death of an individual, to "memoirs" designed "to give posterity something additional by which to remember him," oftentimes as a stalwart defender of the republic. Supporters of the historical, antiquarian, and genealogical societies

13 Weil, Family Trees, 48, 81 (cited), 88, 120, 127, 133 (quotation from the DAR), 141.

14 Gail R. Redmann, "Archivists and Genealogists: The Trend Toward Peaceful Coexistence," Archival Issues 18, no. 2 (1993), 121.

15 Jean M. O'Brien, Firsting and Lasting: Writing Indians Out of Existence in New England (Minneapolis and London: University of Minnesota Press, 2010), xii.

16 John A. Schutz, A Noble Pursuit: The Sesquicentennial History of the New England Cenealogical Society, 1845-1995 (Boston: New England Cenealogical Society, 1995), 6.

17 Weil, Family Trees, 62. 
attracted "influential and congenial members" from the ranks of "clergymen or former clergymen, lawyers, medical doctors, politicians, professors, teachers, and business people - men of education, prominence, and (sometimes) wealth." In the case of the New England Historic Genealogical Society (NEHGS), its founding fathers "were amateur, well-meaning men who saw in the deeds of families the threads of patriotism that made the nation strong and prosperous," writes Schutz. "They believed in family history most of all because it revealed important facts about the nation." As he says of the NEHGS, which was formed in part in response to criticisms of past genealogists, and which began issuing its own journal in the 1840 os,

They wanted a place to discuss New England history, American traditions, and their own family history. They gathered mostly as a group of amateurs infatuated by ancestry, antiquity, and heraldry. The catholicity of their interests helped them to be tolerant of each other and congenial toward a broadly-based male membership. ${ }^{18}$

The British genealogist Sir Bernard Burke thought that Massachusetts in 1863 was "more genealogical than Yorkshire." ${ }^{19}$ Although he finds stirrings of a fascination with the past and a concern for the preservation of its relics in the mid-Atlantic states, Weil finds that "antiquarians were mostly New Englanders." Often, he observes, genealogists presented themselves as "brave, erudite, but lonesome knights," selflessly pursuing acts of research for altruistic ends over years and years - and it pays to note they were almost all heroic male "knights." 20

This New England passion for genealogy - in its second, third, and fourth meanings - thus went well beyond a personal interest in one's immediate family to a far more ambitious interpretation of history in general. Often drawing upon traditions of Puritan piety, genealogy provided religious exaltation as well as a sense of social and cultural belonging. It told the descendants of White settlers not only that they had founded New England, rescuing it from original inhabitants who could be erased from the record, but that God had

18 Schutz, Noble Pursuit, 3, 7, 11, 228, vii. The societies included the Massachusetts Historical Society (1791), Boston Athenaeum (1807), the American Antiquarian Society (1812), the Essex Historical Society (1821), the Rhode Island Historical Society, and the Maine Historical Society (both 1822) as well as the NEHCS. 
favoured their doing so. The stories of the powerful men who made this Godly enterprise possible were not just the only ones that mattered but the only ones that existed. As Lorenzo Veracini explains, settler colonialism is premised on "the domination of a majority that has become indigenous (settlers are made by conquest and by immigration)." It entails not accessing the labour-power but rather acquiring the land and natural resources of the peoples who were on the land before the arrival of the settlers, and it generally entails the erasure of such prior inhabitants from public memory and history. ${ }^{21}$ Genealogy and settler colonialism went together: exalting settlers has often meant erasing those upon whose lands they "settled."

In the 1920s, the cult of the Mayflower suggested the potency of combining genealogy with patriotism. To authenticate one's descent from one of the 102 passengers who arrived in 1620 at what is now Plymouth, Mass., meant obtaining a coveted stock of cultural capital. ${ }^{22}$ The certification of Mayflower status was under the jurisdiction of the General Society of Mayflower Descendants (established 1897). ${ }^{23}$ One corporate investor based in Boston developed "a biographical listing of all known descendants of Mayflower passengers into some 20,600 pages of documents." The 1920s were especially the Mayflower years, in which "New England's contributions to the United States were celebrated with plaques, memberships, and named bequests." ${ }^{24}$ Debates over the signers of the Mayflower compact would consume precious human energies for a century or more, driven by a drive for social distinction but frustrated at many turns by contradictions and aporia in the genealogical record. ${ }^{25}$

21 Lorenzo Veracini, Settler Colonialism: A Theoretical Overview (London: Palgrave Macmillan, 2010), 5.

22 Pierre Bourdieu, Distinction: A Social Critique of the Judgment of Taste (Cambridge, MA: Harvard University Press, 1984), 170, 144.

23 For the society's present activities, one can today consult its home page: https://www. themayflowersociety.org. It is now estimated that tens of millions of Americans can establish some genealogical connection with the Mayflower. The society actively solicited the names of genealogical researchers who might pursue leads in Nova Scotia; see Lewis E. Neff to the Nova Scotia Historical Society, 25 March 1959, RG 53, vol. 20 (1959), PANS and C.B. Fergusson to Neff, 2 April 1959, RG 53, vol. 20 (1959), PANS.

Schutz, Noble Pursuit, 98, 231.

See Akenson, Some Family, 211-12. Blakeley related the story of an American visitor to PANS "who had a desperate longing to be a member of the Mayflower Society, a membership which carried a great deal of 'stature' in her town. The woman came to Halifax and while searching through old records found the necessary 'evidence' required for membership in the society. She promptly burst into tears and sat there in the Archives, sobbing with joy." See Phyllis Blakeley, "Forty Years at the Archives," November 1985, MC1, vol. 3124, PANS. 
And, inevitably, other Americans, unable to claim direct descent from the Plymouth pioneers, developed rival claims to ancestral primacy. Descendants of Huguenots were especially concerned to establish their credentials and affirm their place in American history: "More noble blood never settled American soil than that which circulated through the vein of the Huguenots,' one genealogist boasted in the early 20 th century." ${ }^{26}$ Such rival claims, in opposing the specifics of the Puritan claim to national essence, nonetheless perpetuated the New England template of explaining American history in terms of the cultural, political, and (increasingly) biological excellence of a select group of founding fathers. Some of them, as in the case of the De Forests, the supposed founders of New York City, came with the added bonus of supposed links to European nobility. ${ }^{27}$ Genealogical columns appeared in local historical journals and even newspapers. The Handbook of American Genealogy (1862) had reached its fourth augmented edition by 1900 . Blank family registers proliferated along with other research tools. ${ }^{28}$ "We are becoming the most genealogical nation on the face of the earth," claimed the New York Times in 1879. ${ }^{29}$

\section{"New England's Outpost"}

It was this New England template that exercised a disproportionate influence over Nova Scotia from the 1890 os to the 1920s. In this respect, if not in all others, Nova Scotia - the preoccupation of many a New England 18th-century preacher, statesman, soldier and, from the 1760 os to the 178 os, settler ${ }^{30}-$ was "New England's Outpost," in the resonant phrase of historian J.B. Brebner (1895-1957), who with Harvey exemplified the Depression-era drive for modern, archivally based work. Reciprocally, Boston exerted a strong influence down to the 1950s, both as an economic centre (as a source of capital and a destination for out-migrating working-class Nova Scotians) and as a cultural metropolis.

26 One genealogist cited in Weil, Family Trees, 135-6.

27 As Caron suggests, the "de" of the "De Forests" seemed to some an indication of their noble status. A good many genealogists yielded to variations of "la tentation nobiliaire," even if, in this case, both the nobility and historical significance were largely products of the genealogists' imaginations. See Caron, Se créer des ancêtres, 42.

30 John Bartlet Brebner, New England's Outpost: Acadia before the Conquest of Canada (New York: Columbia University Press, 1927; repr. Hamden, CT: Archon Books, 1965); Brebner followed up with his equally innovative The Neutral Yankees of Nova Scotia: A Marginal Colony During The Revolutionary Years (New York: Columbia University Press, 1937; repr. Toronto: McClelland and Stewart, 1969). 
Yet if one were determined to follow the New England genealogical model and develop a master narrative of Nova Scotia's heroic and pious White Anglo founders, some daunting complications were bound to follow. If the founding fathers of the NEHGS fuelled their years-long efforts in dusty archives with the thought that by doing so they were celebrating the true founders of the Republic, what could inspire their fellow antiquarians in the Nova Scotia Historical Society (NSHS, established 1878)? Some of the families in question, having arrived as Planters or Loyalists, could be figured more easily as founders of their home communities in New England than of those in Nova Scotia; moreover, many of their descendants had returned to New England, all of which made it difficult to claim them as the men who made Canada great. If it seemed obvious to many genealogical chroniclers of American history that the American Revolution was organized by their freedom-loving ancestors following the same script that had caused them to pursue liberty a century earlier, both the "Planters" who had come to Nova Scotia in the 1760 s and 1770 and the "Loyalists" who had arrived in the 1780 os had somehow, despite their ancestry, failed to master this script. ${ }^{31}$ From the Nova Scotia perspective, the putative Loyalist founders were even more problematic since they arrived as the third major group of Europeans and enjoyed a not wholly undeserved reputation as privileged and ultimately unsuccessful elitists. Across Canada there was (and there still is) a determined cadre of history enthusiasts for whom the Loyalists are the foundational Canadians, who developed associations that paralleled the Daughters of the American Revolution, and took up the quest of genealogical credentials as a serious business; but, despite their best efforts, the Loyalist Myth has never become Nova Scotia's Myth..$^{32}$

31 To this day, budding US genealogists are solemnly warned, in no less authoritative a contemporary text as The Complete Idiot's Guide to Genealogy, that they might find skeletons in the family closet - "You Won't Find Perfect People" - with a prime example being relatives who were scandalously located on the "other side" in the Revolutionary War. See Christine Rose and Kay Germain Ingalls, The Complete Idiot's Guide to Genealogy (New York: Alpha Books, 1997), 9.

32 See David V.J. Bell, "The Loyalist Tradition in Canada," Journal of Canadian Studies 5, no. 2 (May 1970): 23-33; Bell, Early Loyalist Saint John: The Origin of New Brunswick Politics, 1783-1786 (Saint John, NB: New Ireland Press, 1983); Bell, Loyalist Rebellion in New Brunswick: A Defining Conflict for Canada's Political Culture (Halifax: Formac, 2013); Jo-Ann Fellows, "The Loyalist Myth in Canada," Historical Papers of the Canadian Historical Association (1971), 94-111; Norman Knowles, Inventing the Loyalists: The Ontario Loyalist Tradition and the Creation of Usable Pasts (Toronto: University of Toronto Press, 1997); and Alison Norman, "'A highly favoured people': The Planter Narrative and the 1928 Grand Historic Pageant of Kentville, Nova Scotia," Acadiensis 38, no. 2 (Summer/Autumn 2009): 116-40. As Neil MacKinnon notes in chap. 6 of This Unfriendly Soil: The Loyalist Experience in Nova Scotia 1783-1791 (Montreal and Kingston: McGillQueen's University Press, 1989), the Loyalists' attitudes tended toward negativity and loss of faith in their supposed cause and a large proportion of them returned to the United States. 
What might seem obvious to New Englanders - that their Puritan forebears were the Great Men who founded the country - was thus not obvious in Nova Scotia, especially since so many of these worthies had, after their Nova Scotia sojourn, pursued fame and fortune elsewhere - often in the United States. After Confederation in 1867 , the nation-state to which many "Nova Scotia" Planters and Loyalists contributed was not the one in which Nova Scotia was located. A common fin-de-siècle pattern was to assert that the contribution of the noble ancestor in question lay in his having built a transnational community of the people of British race. Genealogists - at least those of categories (2), (3), and (4) - focused on White colonizers, who were thought to have "settled" or "planted" Nova Scotia. The most flamboyant of those championing founding whiteness were those who thought the Norse had settled near Yarmouth and left behind a "runic stone," reportedly first discovered c. 1812 but famous only after it was championed by an emissary of the Numismatic and Antiquarian Society of Philadelphia in 1880.33 There ensued many imaginative flights of genealogical fantasy about Nova Scotia's founding White people, all of them extreme versions of a far-more-pervasive pattern of "Firsting and Lasting," in which Indigenous peoples were either forgotten as "pioneers" or imagined to have vanished altogether. ${ }^{34}$

According to liberal settler-colonizer ideology, European settlers, "discovering" an unsettled wilderness, brought with them civilizing qualities - property, social order, religion, individualism, and political freedom which gave them not only the right but also the duty to develop communities embodying them. In the emerging official history of Nova Scotia, of these settlers the British were primae inter pares, whose superiority in civilization and arms gave them the right to prevail over other European claimants. Thus the true founders of Nova Scotia were not those who came first - the Indigenous peoples or, among Europeans, the French - but the British, who, whichever side they chose in the 1770 s and 1780 os, were united by their purportedly Manifest Destiny to build free societies in North America. Both sides of the conflict that split the empire and divided many New Englanders in Nova Scotia from those in New England could be seen as the White colonizers who settled the continent, an achievement far bigger than their momentary political divisions.

33 See Ian McKay and Robin Bates, In The Province of History: Tourism and the Romance of the Past in Twentieth-Century Nova Scotia (Montreal and Kingston: McGill-Queen's, 2010), 317-18.

34 See O'Brien, Firsting and Lasting, which details many New England cases very reminiscent of Nova Scotia. 
In a version of Benedict Anderson's "Reassurance of Fratricide," the conflict between Rebels and Loyalists could be presented as a long-ago war between now happily reconciled brothers whose remembrance of their past conflict confirmed their shared values, i.e., that of bringing the civilization and order of the British race to North America. ${ }^{35}$

Judge A.W. Savary (1831-1920), one of the major genealogical Nova Scotian genealogical writers of the 1890 os, caught this spirit of anglospheric unity by quoting Virgil's Aeneid: "Sic genus amborum scindit se sanguine ab uno," which might be roughly translated as "Thus from one stock, do both our stems divide." He went on to write reassuringly of the reconciliation of the two fraternal "stocks":

The national and personal animosities of that day have been buried in oblivion. To our American neighbors as the victors we look for magnanimous sympathy and respect in the enjoyment of our own independence and national rights as part of the old empire and subjects of the flag of our choice; thus reciprocating the sentiments which our government and people ever seek to manifest towards them, while each of us "under his own vine and fig-tree" may be allowed to glory with an appreciable and mutually respected pride and in friendly and generous rivalry in the free institutions and national prosperity which all have alike inherited from their forefathers.

Striking the pose of the chivalrous knight, embarked upon a soul-testing quest, Savary wrote passionately of the deep sacrifices he had made for the cause of genealogy:

The correspondence involved was enormous, and the expenses incurred so extraordinary that the financial loss will be great relatively to that resulting from the preparation and publication of most works of the same nature. Such books are expected to repay the cost of publication, and sometimes partially or wholly the expenses of researches, but the work of compiling and writing is a "labor of love." ... What was at first the indulgence of a taste for antiquarian

35 Benedict Anderson, Imagined Communities: Reflections on the Origin and Spread of Nationalism (London and New York: Verso, 1983), 199-200. 
research, family history, and speculations in heredity, gradually grew into a herculean task, which I more than once seriously contemplated abandoning in despair. ${ }^{36}$

Although Savary does discuss some happenings in Nova Scotia, by far the greater part of his genealogical opus dwells upon New England. He published in the New England Historical and Genealogical Review, conducted an extensive correspondence with his Massachusetts relatives, and devoted a considerable portion of his Boston-produced book to the genealogy of the separate Severy line of Plymouth County, which he had first mistakenly assumed must have been made up of his blood relatives. Savary greatly admired the tenacity and forbearance of his ancestors, and (quite unusually) even made space within his pantheon of heroes for a woman. ${ }^{37}$ For this Nova Scotian, a study focused on his virtuous family was necessarily focused on its New England days.

Many "category-2 genealogists" active in Nova Scotia were residents of New England. The "labours of . . patriotic Nova Scotians in exile," in the words of D.C. Harvey in 1931, were in evidence from the 1890 s to the 1920 s. $^{38}$ Undoubtedly the doyen of these Nova Scotia patriotic genealogists in exile in New England was A.W.H. Eaton (1849-1937). Born in Kentville into the family of a school inspector, a direct descendant of a notable New England settler, and raised in a religious atmosphere in which his father's Calvinism and his mother's Anglicanism vied for his loyalty, Eaton spent much of his adult life wrestling with questions of religious faith. From 1886 and for about 20 years he supported himself by "preparing New York boys in English for the leading eastern colleges, Harvard, Yale, Princeton and Columbia," brought out a manual on "Letter-Writing, its Ethics and Etiquette," and produced volume after volume of romantic poetry - much of it sanctifying the landscapes of Nova Scotia.

It was as a genealogist and local historian that Eaton won his greatest renown in the province, in works that ranged from pieces praising his own family to such articles as "Chapters in the History of Halifax, Nova Scotia" and

\footnotetext{
36 A.W. Savary, A Genealogical and Biographical Record of the Savery Families (Savory and Savary) and of the Severy Family (Severit, Savery, Savory, and Savary); Descended from Early Immigrants to New England and Philadelphia with Introductory Articles on the Origin and History of the Names, and of English Families of the Name Savery in its Various Forms ... (Boston: Collins Press, 1893), 35-6, iii-iv. devotion to her Christian and familial duties. 
"Rhode Island Settlers in Hants County, Nova Scotia" in Americana magazine from 1913 to $1919 .{ }^{39}$ In his own and many other minds, Eaton's most important work was published in Salem, Mass., in 1910: A History of Kings County Nova Scotia, Heart of the Acadian Land, Giving a Sketch of the French and their Expulsion, and a History of the New England Planters who Came in their Stead..$^{40}$ This was a book of 898 pages, and roughly 38 per cent of them were comprised of pages devoted strictly to genealogies, with a further 9 per cent dedicated to family biographies. Eaton spent three hard years on it, doing all his writing in the NEHGS library in Boston. He confessed that, had he sought to compose "complete family histories, several lifetimes would have been demanded and many volumes required to be filled," but he hoped that "the families themselves" would carry on this work: if they received "an impulse for more thorough genealogical research on their own part, the author's purpose in making them shall have been fully served." Eaton generated many of his insights from published sources, but he also solicited information through notices in the press, histories, and memories from "the families." He also relied on cemetery records and oral traditions; in one case, he reported on direct impressions of the Expulsion of 1755 as they had been passed on through the generations. He also relied heavily upon the prior researches of Dr. William Pitt Brechin, a Boston physician who was also well known as an "indefatigable genealogist of Cornwallis families" and compiler of invaluable scrapbooks, a genealogical achievement hailed in the "fifty-fourth volume of the New England Historical and Genealogical Register." Brechin's work was all the more indispensable because the Horton vital records had evidently disappeared, legislation regarding vital statistics were never enforced, and "of the families of the New England planters in Kings County after three generations, except in probate records or deeds, we are unable to find any public records at all." Eaton

39 A.W.H. Eaton, "Chapters in the History of Halifax, Nova Scotia," "Rhode Island Settlers in Hants County, Nova Scotia," and "Alexander McNutt the Colonizer," printed in Americana, 1913-1919, bound together in a collection at the University of Toronto, and available at https://ia801404. us.archive.org/18/items/1913t19chaptersinhistor00eatouoft/1913t19chaptersinhistorO0eatouoft. pdf. For more on Eaton, see the A.W.H. Eaton fonds, MG1, vols. 277-311, PANS.

40 Arthur Wentworth Hamilton Eaton, The History of Kings County Nova Scotia, Heart of the Acadian Land, Civing a Sketch of the French and their Expulsion; and a History of the New England Planters who Came in Their Stead, with Many Genealogies, 1604-1910 (Salem, MA: Salem Press Company, 1910). In the eyes of W.C. Milner, Eaton had produced "probably the greatest county history in Canada"; see W.C. Milner to D.C. Harvey, 12 April 1932 (private), RG 53, vol. 2 (1932), PANS. 
noted the wide range of people across the province who had helped him make up for this dramatic evidentiary gap..$^{41}$

Although the book never lays out a clear thesis, its implicit message was that New England and Kings County were virtually as one. The "settled history" of Nova Scotia began with Cornwallis and, in the case of Kings County, entailed the arrival of Planters, a few of whom were from Massachusetts and Rhode Island. But most came from "those beautiful old towns" of "four Connecticut counties, New London and Windham, Middlesex and Tolland," which were made up of "worthy gentlemen and prominent persons in the several towns where they belonged." "If any one will take the trouble," Eaton wrote, "to examine the admirable histories of New London and Norwich, ... or the now rapidly increasing later town and family histories of eastern Connecticut, he will see how important the families were from whom are descended the people who have inhabited and still largely inhabit the county whose annals this volume is written to preserve." Of many families settling in Horton and Cornwallis, Eaton remarks that many of them

had intermarried in Connecticut, and to untangle the relationships that existed among them when they came to the county would be a difficult, though very interesting task. So interrelated were the Horton families, for example, in Connecticut, that in tracing their history we feel as if we were tracing the relationships not of many families to each other, but of one great family among its various branches. In the latter part of this volume brief genealogical sketches of many of these related families will be found, but it would take a lifetime of research to compile anything like complete genealogies of the families of all the grantees.

Such direct connections between New England and Nova Scotia allowed Eaton to derive, from probate records and a long description of a New London wedding, conclusions about social life in Kings County itself. When probing

41 Eaton, Kings County, x, 146, xi-xii. In addition to the help of the librarian and staff of the NEHCS, Eaton paid tribute to a network of historians and genealogists in both Nova Scotia and New England: Judge Savary of Annapolis, Miss Annie Donohue, the acting librarian of the Nova Scotia Historical Society, and historian E.M. Saunders were acknowledged among the Nova Scotians, while thanked New Englanders included individuals from Greenwich, Boston, and Winterport, ME. He paid special tribute to Dr. Benjamin Rand, whose "loyal labour in summer vacations" entailed copying out completely "the vital records in the Cornwallis Town Book." 
the New Light religious revival that roused the county in the 1770 s and 1780 s, to give a further example, he made direct reference to the Proceedings of the Massachusetts Historical Society for $1888 .{ }^{42}$

A second implied thesis was that these New Englanders, by virtue of their moral and hereditary excellence, had an almost biological right to the properties they claimed. As one American historian, fully quoted in Eaton's text, exclaimed:

\begin{abstract}
Lebanon, Connecticut, has had a remarkable history. No town in the whole country has compared with it in the number of leading professional men it has furnished to the nation. The first settlers, who went there from 1695 onwards were of superior stock, the very best intellectual and religious material for "a new plantation" that Northampton, Norwich, etc., could furnish.
\end{abstract}

Thus, although they farmed lands once possessed by the Mi'kmaq, tilled by Acadians, and conquered by the British, Eaton's New Englanders were nonetheless the founding White settlers, constituting the primary "stock" of Kings County and, indeed, Nova Scotia. By contrast, Eaton's Mi'kmaq are pathetic, simple-minded remnants of a vanished time, more to be pitied than blamed. ${ }^{43}$ The New Englanders were the settlers and colonizers whose acquisition of property in the Annapolis Valley allowed for "that spirit of independence and sense of liberty" characteristic of New Englanders throughout the continent. ${ }^{44}$ Unlike many American genealogists, then, who could easily imagine that the White men about whom they wrote had founded the United States, Eaton's conflation of "race, heredity and nationalism" was inherently transnational in its scope. His heroic pioneers were founding a settler-colonial order in all of North America, not just in Canada or Nova Scotia.

For Eaton was not just writing a local history of Kings County but a hymn of praise to the New England planters, whose descendants "in not a few cases have carved out for themselves brilliant careers," a pattern that "will not seem

\footnotetext{
42 Eaton, Kings County, 62-3, 70, 71-2, 213, 221-2.

43 Eaton, Kings County, 145: "They were simple-minded, harmless, gently-moving people, some of whom, like 'old Madeline' lived to the age of a hundred years, but most of whom died of exposure and poor living at a much earlier age." To be fair to Eaton, his is a much more sympathetic portrait than others presented in the first half of the 20th century.

44 Eaton, Kings County, 395, 70, 161.
} 
strange when one remembers the fine qualities of the stock from which most of them sprang." This was ultimately a conservative vision of a county justly led by a distinguished group of families, who

with untiring industry replanted the long tilled but now vacant upland soil, rebuilt and enlarged the great marsh spaces reclaimed from the sea by their predecessors, set out new orchards, sowed flourishing fields of flax and corn, built churches, established schools, and by their intelligence and piety laid the foundations for a college, where, in one of the loveliest regions in eastern America, for seventy years now, sound learning has been constantly fostered and solid principles have been taught.

The county's towns fell under the leadership of "a group of intelligent, well-bred men and women, of more or less education as the case might be, but of refined instincts and cultivated tastes," whose family names consume many lines of the History. ${ }^{45}$ The truly attentive reader will also spot that 18 th-century Kings County harboured slaves, dispossessed Acadians, and very poor people, some of them subjected to the indignity of being auctioned off as unpaid labourers to the highest bidder at auctions - but such small islands of social realism are set amidst a sea of ancestral romanticism.

It was entirely appropriate that Wolfville, which once bore "the disagreeable name 'Mud Creek'," now honoured the name of the estimable DeWolfs among whom one found "Judge Elisha DeWolf, the leading man of the village, an important land-owner, who built the house now known as Kent Lodge, and who had the honour of entertaining in his hospitable cottage, H.R.H. the Duke of Kent, when he was journeying from Halifax to Annapolis." It was naturally the case that such excellent families had flourished throughout both Canada and the United States: "As might be expected from the character of the people, a very large number of the sons of Kings County men have gone beyond the grammar schools and other secondary schools of the county, to institutions of higher learning at home and abroad." It was hardly surprising that so many had proceeded to Harvard and other institutions of higher learning, including A.W.H. Eaton himself. Thus was reverent filiopietism combined with selfcongratulatory "autopietism." 46

45 Eaton, Kings County, ix, ix-x, 131, 162, 147, 148-58, 345.

46 Eaton, Kings County, ix, ix- $x, 147,345$. 
Eaton saw himself as engaged in a work of cultural salvage that only he could undertake: "If I had not done Kings County," he told D.C. Harvey,

it would never have been done. After collecting material for it and mulling over this for years I came from New York to Boston and settled down at it for over three years of steady hard work, having a discouraging publisher, but at last I accomplished the task and fortunately I saved the County's history. ${ }^{47}$

If, however, one were a member of his extended family, such as his entrepreneurial cousin Cyrus Eaton of Cleveland, or his other, more philosophical cousin, Benjamin Rand, the Harvard scholar and librarian, the very genealogist hailed so warmly in Kings County, one was likely to be just as impressed by his "notable history of the Eaton Family of Nova Scotia," in the words of one heartfelt eulogy to him. ${ }^{48}$ To this genealogical historian, the history of Nova Scotia was, in a sense, that of the Eatons writ large.

The theme of the New Englanders' moral and biological excellence could be applied well beyond Kings County. Eaton, in the "Halifax Chapters," remarked that the city owed much of its character to "people of excellent standing among the New England commercial gentry to which they belonged," and went on to list 22 such noteworthy families. There followed a long list of Nova Scotians, many of them Haligonians, who had received British knighthoods and other honours - an implicit homage to the common heritage and interests of the British race. And when it came to the New England settlers of Kings and Hants counties, i.e., Eaton's own forebears, he wrote: "It is impossible to speak in too high praise, and one needs only a slight acquaintance with Rhode Island history to know the unusual prominence and worth of the families from that colony that came to Falmouth and Newport." This statement was followed with another long list of the names of the most eminent families. Given how many men with sterling pedigrees had left 18th-century New England, Eaton, a longtime Boston resident, even allowed himself to wonder if the Revolution might

47 A.W.H. Eaton to D.C. Harvey, 8 April 1932, RG 53, vol. 2 (1932), PANS.

48 Anonymous, Arthur Wentworth Hamilton Eaton, M.A., D.C.L., enclosed with A.W.H. Eaton to D.C. Harvey, 5 October 1931, RC53, vol. 2 (D-L), PANS. This laudatory description was based in part on an in-depth profile of Eaton in the Canadian Magazine of 1907, and one surmises it was edited as well as distributed by Eaton himself. 
not have lowered the city's cultural tone and caused the loss of "some of her very finest ideals." 49

Although technically an expatriate, Eaton never ceased to identify himself as a Nova Scotian. He advised one admirer that his History of Kings County was his work of "most permanent value," in large part because it documented "that remarkable migration of New England Families in 1760 to Nova Scotia that took thousands of men and women of the very best New England families to Nova Scotia." Then, in classic filiopietistic style, he rhymed off the great names of this New England tradition:

the great astronomer Simon Newcomb, my cousin Dr. Benjamin Rand, historian of philosophy, my cousin Cyrus S. Eaton, notable Cleveland financier, his uncle Dr. Charles A. Eaton, Congressman and Industrial Welfare Authority, Robie L. Reid, Barrister, Q.C. of Vancouver, British Columbia, and a multitude of other notable men who had achieved distinction away from Nova Scotia, testifying to the worth of the stock they came from.

As he reached his twilight years, Eaton fretted that he had left much of the work of celebrating these and other founding settlers undone. He was especially worried about an extensive collection he had made of genealogical facts in Colchester County, for its loss would constitute a colossal setback for the province:

I do not know of anybody in the world who can continue the history of Colchester or indeed of any other County of Nova Scotia, a county history is a work that demands for many months or years a rare devotion and an understanding that no Nova Scotian that [I] have any knowledge of possesses .... I have longed to see Colchester, Hants, and Cumberland done but I am sure there is now nobody living who can do this.

Notwithstanding this pessimistic sense of an era of genealogical county histories coming to a close, Eaton still held out some hope that the great

49 A.W.H. Eaton, "Chapters in the History of Halifax, Nova Scotia," "Rhode Island Settlers in Hants County, Nova Scotia," and "Alexander McNutt the Colonizer," https://ia801404.us.archive.org/18/ items/1913t19chaptersinhistor00eatouoft/1913t19chaptersinhistor00eatouoft.pdf. 
work of writing Nova Scotia's history, county by county and leading family by leading family, might continue. Eventually a "thorough, readable history" would emerge..$^{50}$

Eaton's "saving Nova Scotia's history" by applying to it the genealogical techniques he had polished in Massachusetts suggested both the similarities and the differences between New England and Nova Scotia. In New England, genealogy was pursued by a formidable elite ensconced within powerful institutions. When they turned their attention to Nova Scotia, it was to find ancestors imagined to be pious, hard-working settlers helping build up the English-speaking settlements that made North America - often by coming back to the United States and rising into the top ranks of entrepreneurs, professors, and lawyers. In Nova Scotia there was some local interest in genealogy, as evident in old "genealogy books" kept in towns like Yarmouth"; the drive to safeguard local township records, which were directly useful for listing property holders and the traditional brands farmers placed on their cattle from the depredations of outsiders (some of them archivists) ${ }^{52}$; columns devoted to recording the deeds of well-known families in the Yarmouth Herald and Halifax Chronicle; a few devoted collectors of genealogical information pertinent to particular communities, such as T. Brenton Smith in Queens County ${ }^{53}$ and Harry Piers of the Nova Scotia Museum, a correspondent of

50 A.W.H. Eaton to D.C. Harvey, 8 April 1932, RG 53, vol. 2 (1932), PANS.

51 RG 53, vol. 13 (1947/8), PANS: Arthur J. McLeod to D.C. Harvey, 8 September 1947; Harvey to McLeod, 10 September 1947; McLeod to Harvey, 10 October 1947; Harvey to McLeod, 10, 16 October 1947; McLeod to Harvey, 7 May 1948; Harvey to McLeod, 10 May 1948; McLeod to Harvey, 14 May 1948; Harvey to McLeod, 27 May 1948; McLeod to Harvey, 15 June 1948; Harvey to McLeod, 18 June 1948; McLeod to Harvey, 24 June, 13 September, 11 October 1948; Harvey to McLeod, 2 November, 14 December 1948; McLeod to Harvey, 24 December 1948. The book was so badly worn through "constant use" that its custodians feared for its safety.

52 J.D. Logan to G.J. Truman, 11 June 1926, RG 53, vol. 1 (1926), PANS. This case comes from Sackville Township, just over the New Brunswick border from Nova Scotia; one imagines the custom of so listing livestock was also found in the latter province. One agent of the Dominion Archives in Ottawa was widely associated with attempts to secure such records and move them out of the province. Some remembered without enthusiasm the depredations of archivist W.C. Milner, who had sent many such documents - "about 249 cases of records" on his own estimate - to Ottawa in his capacity as the Dominion Archives representative; see W.C. Milner to D.C. Harvey, 12 April 1932 (private), RG 53, vol. 2 (1932), PANS. For Milner's record as an archivist in the Maritimes, see Macleod, "Our Man in the Maritimes," 86-105.

53 Ultimately his genealogical data filled "10 boxlike containers" when transferred to PANS in the 1950s. He estimated that as many as 100,000 people had once lived in Queens County - so, having acquired files on about 14,500, he had about "85,000 or so" to go. See T. Brenton Smith to C.B. Fergusson, 19 November 1953; Smith to Fergusson, 30 November 1953, RG 53, vol. 15 (1953), PANS as well as Mrs. Stewart Hamilton Giffin to Archivist, 8 November 1956, RG 53, vol. 17 (1956), PANS. Smith was perhaps the pre-eminent category (4) genealogist in the province. 
and subscriber to Burke's Landed Gentry in London ${ }^{54}$; a minority of the papers read to the Nova Scotia Historical Society ${ }^{55}$; and doubtless innumerable grandmothers and grandfathers keen to impress upon the young the moral lessons acquired from venerable ancestors.

Moreover, there were some more ambitious homegrown attempts at general genealogically flavoured historical interpretations in the 1920s. In 1923, Pictou County resounded to speeches and ceremonies hailing the virtuous ancestors who had sailed a century before on the Hector - just like the Mayflower, the ship could be imagined to be the vessel that started it all.56 That Scots were the primae inter pares of the "White Races" officially promoted by the province in 1936 was one consequence of this pervasive promotion of tartan-themed attractions. ${ }^{57}$ In 1924 the entire province advertised an "Old Home Summer" celebration - a blatant steal from a similar Massachusetts promotion - that enticed American "family and friends" back to re-experience their native province.

Yet all such genealogical enterprises, duly noted, hardly held a candle to the genealogists of all five categories found in more-developed New England, where one found a large leisured class with ample time and resources to create a booming mnemonic sector of the "most genealogical nation on the face of the earth." When they turned their eyes northward, in search of Planter or Loyalist forebears, they were not hoping to encounter difference but kinship often kin who might count towards establishing their own cultural credentials as founding settlers of New England.

A graphic sense of the gap between New England and Nova Scotia can be discerned in the correspondence of A.F. MacDonald, who served in the Halifax Dominion Archives office in the late 1920s. Knowledge that such an office existed excited many a genealogist in the United States, who imagined it would offer services equivalent to those provided by similar American institutions.

54 Journal of Harry Piers, 19 March 1938, MG1, vol. 758, PANS.

55 See, for instance, Collections of the Nova Scotia Historical Society for the Year 1886-87, Volume Five (Halifax: Wm McNab, 1887), which lists some 61 papers read from 1878 to 1887 and of which 8 seem to have been genealogical in nature.

56 See Michael Boudreau, "A 'Rare and Unusual Treat of Historical Significance': The 1923 Hector Celebration and the Political Economy of the Past," Journal of Canadian Studies 28, no. 4 (Winter 1993-94): 28-48; Boudreau draws attention on pp. 31-2 to the important role played by George Patterson, a prominent judge, leading genealogist, son of a renowned 19th-century historian, a prominent local historian in his own right, and a direct descendant of a Hector passenger.

57 See Nova Scotia, Department of Highways, Nova Scotia: Canada's Ocean Playground (Halifax, n.d. [1936]), inside back cover. For a detailed discussion, see McKay and Bates, In The Province of History, 3-17. 
They were swiftly disabused of any such hopes when they arrived in Halifax. To make up for the disappointment of some of them, MacDonald exerted himself heroically to fit ancestors to customers. He received a vague request from a man from Pennsylvania desirous of details about an 18th-century Loyalist marriage in Annapolis Royal. MacDonald answered with a three-page missive dense with arcane data mined from W.A. Calnek's History of Annapolis County and Judge Savary's Supplement to the History of Annapolis. He also roused Laura Hardy of Granville Ferry to search the local probate records, which task she combined with inquiries into the clergyman who might have performed the ceremony. ${ }^{58}$ She seemed genuinely shocked when she received five dollars from the American ancestor-hunter:

Really I was quite distressed at the thought of receiving remuneration for a bit of work which I had done willingly, gladly, with no thought whatever, I assure you, of receiving any reward for it. My "reward was in the doing" - for it afforded me a great deal of pleasure in hunting up the record .... I am very much interested in that sort of thing and in your honouring me by asking me rather than some one else to do it; also in your very kind letter of appreciation. I wish that you had kept half the amount! I feel guilty in receiving it all - and very undeserving of it since I did not get the information required..$^{59}$

Honour, gratitude, reciprocal obligation, historical knowledge for its own sake: we are in the presence of a communitarian ethos quite different from far more hierarchical and commercial genealogical world of the larger American centres. It was one in which, repeatedly, the Archives and its network of supporters provided goods and services virtually gratis to a growing population of American ancestor-hunters.

Thus, when researchers wrote to MacDonald of the Halifax Branch of the Dominion Archives in Ottawa or to his successor Harvey at the Public Archives of Nova Scotia in Halifax, which took over much of the field in 1931 and assumed custody of most of the Dominion Branch's holdings, they often discovered an unwelcome corollary of the difference between the two genealogical cultures. Compared with Massachusetts, Nova Scotia was barely

58 A.F. MacDonald to Kingston C. Hadley, 8, 9 November, 4 December 1929 and Hadley to MacDonald, 9 December 1929, RG 53, vol. 1 (1929), PANS. 
getting started in the field of genealogy. It not only lacked the equivalents of the well-funded elite genealogical societies but also the records requisite for most genealogical searches. Although PANS, founded in 1857, was officially the custodian of rare state papers of Nova Scotia, it was not an institution designed to meet the needs of ancestor-hunting members of the general public. Because vital statistics were not kept in Nova Scotia before 1865, and births, marriages, and deaths were not officially registered until 1908, much depended on the existence of church records, only some of which were readily available and, in almost all cases, not yet available at PANS. ${ }^{60}$ "We have a great many genealogical inquiries," Harvey as archivist announced shortly after the new building's opening, "but not having complete vital statistics anywhere in Nova Scotia it is rather a thankless job trying to do anything with them, particularly as many of the ancestors desired were just ordinary folk who were doing the world's work, and who at most may appear in a census return or a grant for land." ${ }^{\prime 61}$ Many passengers' lists, another promising genealogical resource, had been destroyed, and only a few had been retained in the Archives. ${ }^{62}$ Tracing those with Scottish names remained an almost impossible challenge down to the late 1930s, and it was a difficult one after that since even the systematic organization of land grants data (completed by Margaret Ells and J.S. Martell by 1938) would not be of much help if the Scottish settler in question had been a squatter without land title, a landless labourer, or one of thousands of the Cape Breton MacDonalds. ${ }^{63}$ Some American correspondents simply could not believe that Nova Scotia had no officially registered vital statistics until the 1860 and offered researchers no centralized repository of local data: "Is this true?" asked one incredulously, responding to this discouraging news. "Haven't you Town Rec.? -County Rec.-? Has no one had photo sheet copies made of such \& given, put somewhere?"64

60 Phyllis Blakeley [writing for Fergusson] to Miss Margaret Ross Wilcox, 20 July 1959, RC 53, vol. 20 (1959), PANS. Some of the most significant genealogical resources, such as the Register of the Births, Marriages, and Deaths at Annapolis Royal from 1727 to 1755, were still retained by the Archbishop of Halifax, who might or might not allow them to be loaned out to interested parties; see Leander d'Entremont to A.M. Kinnear, 22 February 1928, RG 53, vol. 1 (1928), PANS.

61 D.C. Harvey to M.M. Lewis, 29 December 1933, RG 53, vol. 5 (1933), PANS.

62 D.C. Harvey to George Patterson, 22 October 1935, RG 53, vol. 5 (1935), PANS. Harvey published the institution's two such lists in the Pictou and Antigonish papers, but the remainder, it seemed, had been destroyed.

Phyllis Blakeley [writing for Fergusson] to Miss Margaret Ross Wilcox, 20 July 1959, RG 53, vol. 20 (1959), PANS.

64 Mrs. Stewart Hamilton Giffin to Archivist, 8 November 1956, RG 53, vol. 17 (1956), PANS. 


\section{Genealogy in Harvey's "historical laboratory"}

This was the situation into which D.C. Harvey stepped in 1931 when he became the provincial archivist. Harvey visualized the Archives as a progressive "historical laboratory," whence would come a steady stream of research tools, documents, and narratives as part of a grand design of liberal enlightenment. In his vision, the Archives, by following a coherent research program focused on the emergence and consolidation of liberal democracy in 19th-century Nova Scotia, was engaged in the pedagogical exercise of rousing citizens to a sense of their responsibilities as inheritors of this tradition. His overarching ambition was the creation of a citizenry well-informed about the emergence of its liberties and appreciative of the British Empire that had purportedly made them possible. Genealogy might be assimilated into this liberal progressive agenda; it should never dominate it.

Harvey's objections to genealogy can be boiled down to four key arguments: it was anti-egalitarian, it might raise questions about the authority of the Archives as a state institution, it conceivably posed a threat to the security of documents, and it meant hours upon hours of hard work on the part of hardpressed archivists with many other, more scientifically valuable things to do.

On the egalitarianism question, Harvey was a conservative liberal and not a socialist; but he nonetheless had little time for rank and ostentation. Those he admired most were, first, the White settlers, and second, the entrepreneurs, successful administrators, and visionary politicians who helped them create a flourishing society. He looked askance at functionless privilege. He responded with high moral dudgeon to people who sought jobs at the Archives on the basis of patronage. Some of this thinly secularized Presbyterianism comes through in his response to the entreaties of H. Percy Blanchard of Ellershouse (1862-1939). Blanchard told Harvey in 1931 that he was "an old lawyer, retired, and feel that I am still alive." Here was one local genealogist - an aspiring category (4) - who hoped to prosper in the new age ushered in by PANS. Once a writer of what is now considered science fiction, ${ }^{65}$ Blanchard also claimed credit for organizing the Baddeck Public Library on the Dewey Model. He advocated what he called the "Arlington System" of genealogy, which assigned

65 In After the Cataclysm: A Romance of the Age to Come (New York: Cochrane Publishing, 1909), Blanchard told the story of a man who awakened in 1934, after a Great War and the Earth's brush with an asteroid ushered in a socialist world state; see http://www.sf-encyclopedia.com/ entry/blanchard_h_percy. 
a number to every child, even to those failing to produce progeny. Here was a method that not only saved "pages of space" but also ensured "accuracy." ${ }^{66}$

In 1931, Blanchard, although possessed of a considerable estate, now found his income "rather limited, so I must economize." ${ }^{\text {" Fo }}$ For years he had toiled in the fields of Blanchard ancestry, "till now I have a very satisfactory record of all the Blanchards of Nova Scotia." Then he had been hired by the businessman and politician Hon. F.B. McCurdy to work on the McCurdys. Not only had he produced enough for the intended volume, but material sufficient to fill a supplement to it. He traced the family back to 15 th-century Chief Gilkrist Mackurerdy and established that

not only were the McCurdys of a family characterized for centuries by a high mental development and belonging to an ancient civilization, but ... they differ in almost every respect from the Picts or Highland people, among whom they were found in 1666, when they left Scotland.

Thankfully, then, they were not Picts or Highlanders but, rather, racially superior Scots, whose very name was linked to the second daughter of King Zedekiah, named Scota, who had escaped from Ancient Judea. ${ }^{68}$ If this seemed a suitably august and religious pedigree for Frederick Blanchard McCurdy, MP, Conservative cabinet minister and renowned figure of the Montreal Stock Exchange, it might also be taken as evidence of a point made by contemporary analysts: family genealogies often tended to be comprised of "truth and falsehoods, the exact and the incorrect, strokes of genius and errors of interpretation," with "historical exactitude" signifying but little. ${ }^{69}$

Nonetheless, for all his fantastical genealogical speculations, which were of a piece with contemporaneous and far-fetched attempts to prove Nova Scotia's supposedly primordial Norse heritage, about which Harvey was a pronounced sceptic, Blanchard was too well-connected for the Archivist simply to dismiss him. He had enlisted the support of Hon. E.N. Rhodes, the former premier and

66 H. Percy Blanchard to Dr. A.S. Mackenzie, 17 June 1931, RG 53, vol. 1 (1931), PANS.

67 H. Percy Blanchard to Dr. A.S. Mackenzie, 17 June 1931, RG 53, vol. 1 (1931), PANS.

68 H. Percy Blanchard, Genealogical Record \& Biographical Sketches of the McCurdys of Nova Scotia (London: Covenant Publishing, 1930); Blanchard, The Ancestral McCurdys (London: Covenant Publishing, 1930), esp. vii, 4. Scota is sometimes represented as a daughter of an Egyptian pharaoh. 
the political godfather of the revitalized PANS itself, who was said to be of the opinion that "as large a collection of genealogies should be had as possible, and as soon as possible." Blanchard wanted to proceed promptly, at the institution's expense, to the preparation of a pamphlet about the renowned Nova Scotia Archibalds. His genealogical enterprise would spur "particular families" throughout the province to "follow their own later pedigrees and have them printed in leaf form." More ambitiously, he laid out for Harvey a complicated scheme for the collection of the genealogies - including details even as to how the charts should be typed out and bound - which once assembled would constitute a provincial "genealogical tree book." He also recommended that the Archives itself publish 500 copies of his system, "ready to hand for any ambitious Genealogists," and publicize this methodology through a publicly funded newspaper campaign. ${ }^{70}$

This genealogist presented his scheme as a step towards a truly modern genealogy, yet its fusty odour of elitism was palpable. President A.S. Mackenzie of Dalhousie University, who was also vice-chairman of the Archives' Board of Trustees, commended Blanchard's enthusiasm, but then went on to distinguish what he took to be PANS's new progressive vision from Blanchard's pedigreeobsessed design:

Our first aim will be to gather in every book, picture, map, letter, pamphlet, etc., that will throw any light on the foundation and development of Nova Scotia. This will include, of course, any material of any kind that deals with the men, high or low degree, who have a part in the making of the history of Nova Scotia, whether they be, officials or farmers or artisans, etc. ${ }^{71}$

For his part, Harvey politely thanked Blanchard for enabling him "pretty clearly to see your idea of what the Provincial Archives of Nova Scotia should be" while firmly declining to follow his lead. ${ }^{2}$ Harvey also refused to provide free storage at PANS for some 900 copies of the Ancestral McCurdys. He suggested that they might instead be placed "in the hands of every living McCurdy known" and also distributed to the province's libraries: "I fear that if they were stored in the Archives they would displace something for which

70 H. Percy Blanchard to D.C. Harvey, 2 September, 18 December 1931, RC 53, vol. 1 (1931), PANS.

71 A.S. Mackenzie to H. Percy Blanchard, 17 June 1931, RG 53, vol. 2 (1932), PANS.

72 D.C. Harvey to H. Percy Blanchard, 5 September 1931, RG 53, vol. 1 (1931), PANS. 
we are supposed to be specifically responsible and that there would not be any perceptible sale to justify a public institution assuming responsibility for them." ${ }^{73}$ He was unimpressed, one imagines, with the Tale of Zedekiah.

The rather different challenge presented by Pubnico-based H. Leander d'Entremont (1862-1944) raised a second problem with genealogy: it might decentre the archives itself as an official repository of certified historical facts and fount of settler wisdom. Having returned to Nova Scotia after a long sojourn in New England, d'Entremont was a frequent contributor to the Halifax Chronicle on matters historical and genealogical - especially those concerning his re-adopted Acadian community, which in his eyes had been very much shaped by a distant Golden Age of French colonialism. D’Entremont claimed direct descent from Charles de Saint-Etienne de la Tour, the Governor of Acadia from 1631 to 1642 and 1653 to 1657 . He was sufficiently well-connected that he was entrusted by the Archbishop of Halifax with a precious register of births, marriages, and deaths. ${ }^{74} \mathrm{He}$ was also, in 1931, in touch with archivist A.F. MacDonald of the Halifax Dominion archives about obtaining a copy of a land grant from Oliver Cromwell to the la Tours, along with a map:

Now, Mr. MacDonald, that is a document which is of great interest to me, as is the map, as it has to do with my ancestors. I am very anxious to get a copy of that document and a photostat of the map, as it may be of great value to me in compiling the history of my family. Could you favor me immediately with copies of them? ... The Department of Archives should be glad to help those who are trying to get at the bottom of historical facts.

In return, d'Entremont promised to send the Archives a copy of his soon-to-bepublished The Baronnie de Pombcoup and the Acadians..$^{75}$ MacDonald loaned him the documents, apparently free of charge. ${ }^{76}$

D'Entremont vaunted his "d'Entremont Collection," an archive containing as it did 10,000 pages of material "which, if typewritten, would make [up]

73 D.C. Harvey to H. Percy Blanchard, 25 November 1936, RG 53, vol. 6 (1936), PANS.

74 Leander d'Entremont to A.M. Kinnear, 22 February 1928, RG 53, vol. 1 (1928), PANS.

$75 \mathrm{H}$. Leander d'Entremont, Baronnie de Pombcoup and the Acadians: A History of the Ancient Department of Cape Sable, Now Known as Yarmouth and Shelburne Counties, Nova Scotia, in Three Parts (Yarmouth, NS: Herald-Telegram Press, 1931).

76 H. Leander d'Entremont to Alvin F. MacDonald, 21 January 1931, RG 53, vol. 1 (1931), PANS; A.F. MacDonald to d'Entremont, 21 January 1931, RC 53, vol. 1 (1931), PANS. 
probably more than 3,000 pages." Here was an "encyclopedia of Acadian history," containing "quite a number of documents and letters that have never been published in this country." 77 He was also proud of his Musée de la Tour, wherein (on Blakeley's 1938 description) one could encounter not only prized genealogical records but also the family coat of arms (dating, perhaps, all the way back to 1020), a wall case full of old French documents, a sword fashioned from the appendage of a sword-fish, and a violin made by one of his ancestors. ${ }^{78}$

In 1928, writing under the letterhead of "Chateau d'Entremont," a title that may rather have overstated the aristocratic ambience of his humble Pubnico dwelling, d'Entremont wrote to archivist A.F. MacDonald for militia records, which, he maintained, would reveal that the local Acadians "were always loyal to England." 79 Access to archival records in distant Halifax was essential, and he felt that, given the importance of his work and perhaps (by implication) his connection with nobility, they should be loaned out to him. He had heard tantalizing rumours about a "trunk load" of Acadia-related documents in Halifax. If these rumours were accurate, the situation called out for the services of "a competent person with knowledge of both English and French, and who could arrange them in their proper order." D'Entremont undoubtedly believed himself to be that very person. As had been the case with Blanchard, d'Entremont was an old man seeking employment in Depressionera Canada. He hoped to transform his genealogical passion into a source of income. D'Entremont suggested that the Archives pay him \$500 to type out and index the 93 volumes in his collection, whereupon he would give them the originals - a bargain for a collection that had cost him (and here he struck the genealogists" characteristic note of altruistic self-sacrifice) "about \$3,000 in time and money."

D'Entremont entered into an extensive correspondence with Harvey in 1932. As he told Harvey, even d'Entremont's local MLA had expressed interest in "the historical work I have undertaken to develop in this section of our Province.” D’Entremont himself had also been active in providing genealogical services to Maritime-born correspondents in distant California. ${ }^{81}$ Yet now he felt the urgent need to consult the "missing link" in Acadian genealogy,

77 H. Leander d'Entremont to A.M. Kinnear, 19 March 1928, RG 53, vol. 1 (1928), PANS.

78 Phyllis Blakeley Diary, 30 December 1938, Phyllis Blakeley Fonds, MG 1, vol. 3184, PANS.

79 H. Leander d'Entremont to A.M. Kinnear, 14 February 1928, RG 53, vol.1 (1926), PANS.

80 H. Leander d'Entremont to Alvin F. MacDonald, 18, 23 March 1929, RG 53, vol. 1 (1929), PANS.

81 H. Leander d'Entremont to D.C. Harvey, 24 May 1932, RG 53, vol. 2 (1932), PANS. 
the first Register of Port Royal from 1702 to 1727, which recorded "the births, Marriages and deaths of the Comeau family." In essence, he wanted PANS to follow MacDonald's example and send him the register, or else to arrange to have someone with good French copy out all the names. ${ }^{82}$

Harvey confirmed that the archives did indeed have the register and agreed to allow d'Entremont or his delegate to make transcripts, but (evidently unlike his predecessor MacDonald in the Dominion branch) he declined to go any further than that on the grounds of safeguarding the documents' security. ${ }^{83} \mathrm{He}$ likely also had little appreciation for d'Entremont's championing of an alternative imperial narrative. From d'Entremont's perspective, Harvey seemed a haughty Anglo Halifax bureaucrat denying a hard-working Acadian genealogist access to invaluable resources. It seemed a case of willful disregard of a minority that confirmed suspicions of linguistic and ethnic bias d'Entremont had raised with Harvey's predecessor: "I have never heard of an Acadian being employed in the Archives, at Halifax, ... and, as the Acadians consist of more than a tenth of the population of the Province, I have often wondered why none were ever in the department." More pointedly, he went on to ask: "Are there no Acadians, in Nova Scotia, with enough intellectual ability to hold a position with the Nova Scotia Department of the Archives? I wonder." ${ }^{84}$ Such an Acadian might challenge the inaccuracies and aporia in existing genealogies. ${ }^{85}$

This was one of the few times in this period in which a subaltern directly confronted the Anglo grip on genealogy in Nova Scotia. Since one of the primary motivations for forming the archives in the first place had been to defend the province against imputations of cruelty to Acadians, d'Entremont was touching an exposed nerve. ${ }^{86}$ It is little wonder that Harvey came to see him as an oppositional figure who, despite his earnest attempt to prove Acadian loyalty to the Crown, might nonetheless seem to be questioning the institution's very raison d'être and its claim to stand for the heritage of all Nova Scotians. ${ }^{87}$ The two of them would fight it out through the 1930s, in a battle in which

82 D.C. Harvey to H. Leander d'Entremont, 11 June 1932, RG 53, vol. 2 (1932, D-L), PANS.

83 H. Leander d'Entremont to D.C. Harvey, 24 May 1932, RG 53, vol. 2 (1932, D-L), PANS.

84 H. Leander d'Entremont to Alvin F. MacDonald, 18 March 1929, RG 53, vol. 1 (1929), PANS.

85 H. Leander d'Entremont to A.M. Kinnear, 19 March 1928, RC 53, vol. 1 (1928), PANS. Such errors, in d'Entremont's view, were especially apparent in the work of Rev. Edwin Crowell of Yarmouth, whose History of Barrington Township and Vicinity ... with a Biographical and Genealogical Appendix (Yarmouth, NS: n.p., 1923) was full of errors when it came to Acadian genealogy.

86 See Cuthbertson, "Thomas Beamish Akins."

87 As Caron (Se créer des ancêtres, p. 22), points out, genealogical researchers were working to shore up the nationalist narratives of both French Canadians and Acadians. The sensitiveness of French/English issues at the HSMBC, of which Harvey was a leading member, is explored by 
d'Entremont explicitly challenged Harvey's competence as a local historian as well as his impartiality as an interpreter of the province's history. If some of the debate seemingly revolved around a precise, indeed minute, issue - the exact location of Fort La Tour - in it d'Entremont also directly challenged Harvey's authority as a supposedly aloof and blinkered Halifax bureaucrat indifferent to the hard-won fruits of honest researchers such as himself. ${ }^{88}$

Far more congenial was Henry C. Ritchie, the local historian of Saratoga County, New York, who spent many of his winters copying and indexing the vital records of townships in the vicinity. During the summer, however, he returned to his native Pictou County, where he devoted himself to transcribing cemetery headstones. ${ }^{89}$ In 1956, Ritchie estimated his expenses of traveling to Nova Scotia, living away from home, and "in the field" had amounted to no less than $\$ 500$ over four weeks. He did not include in this estimate the unpaid labour of his wife "not only in actual copying, but in the much longer job here at home of transcribing."9o Such was Ritchie's martyr-like scrupulosity that he submitted to the Archives a list of his own mistakes in the more than a dozen books, each of them about 200 pages in length (with 20 names per page), resulting from his "crop of Pictou County Cemeteries." The equally empiricist Harvey could only express his "continued admiration for your enthusiasm." ${ }^{11}$

When Ritchie's records were presented to PANS in September 1957, after his death, the greater cultural stakes involved in his zealous graveyard adventures became clearer. His "great achievement" was lauded as one that should "awaken in all a proper sense of devotion and deference to the ancestors who had kept Canada British." His eulogist evoked the conquerors of the Plains of Abraham and the moving sight of Chester Cathedral in England, wherein was displayed "an old, thin, faded flag under which they marched to victory nearly two

Roger Marsters, "'The Battle of Grand Pré': The Historic Sites and Monuments Board of Canada and the Commemoration of Acadian History," Acadiensis 36, no. 1 (Autumn 2006): 29-50.

88 See McKay, "Public History, Disputatious Antiquarians, and Awkward Ancestors."

89 This was a genealogical practice upon which, in 1903, both the New England Historical and Genealogical Register and the Essex Antiquarian had lavished their attention; see Schutz, Noble Pursuit, 76.

90 Henry C. Ritchie to D.C. Harvey, 26 June 1956 and Harvey to Ritchie, 15 February 1956, RG 53, vol. 17 (1956), PANS.

91 Henry C. Ritchie to D.C. Harvey, 16 January 1952 and Harvey to Ritchie, 19 January 1952, RG 53, vol. 15 (1952), PANS. Ritchie's worries were, evidently, not misplaced: the contemporary Archives finding aid concludes with this: "Please Note! In a work of this size errors are bound to appear. We ask all of those using the Ritchie Records not to make any alterations in any of the material." 
hundred years ago.” In Pictou, such noble ancestors had created a Presbyterian society in which every child over the age of five was

introduced to technical genealogy, through hearing the genealogy of Jesus Christ at church or in the home: The Gospel of St. Matthew, Chap. 1 Verse 1: The generation of Jesus Christ, son of David, son of Abraham: Abraham begat Isaac, Isaac begat Jacob, Jacob begat Judas and his brothers, and so on. These endless chains of Humanity twine and intertwine..$^{22}$

In short, the early Pictou pioneers were very much like the founders of the Christian church in their piety, resourceful, kindness, mutual helpfulness, and egalitarianism - not to mention their exemplary passion for genealogy True Pictonians realized that, in the matters that counted, the American Ritchie had served the noble project of documenting White settlers as they colonized North America, one with which Britons, Americans, and Nova Scotians should all identify. Race, heredity, religion, Anglospheric nationalism, and noble individualism were all potently combined in this transnational vision.

During the 1950s, Ritchie wanted the Archives to store his research notes and, after much hesitation, the institution agreed to do so; archivists for years afterwards lived with the consequences of some of Ritchie's inaccuracies, which provoked a lot of to-and-fro with visiting researchers. In this case as in so many others, the institution argued that the place for all such vulnerable records was the fireproof Archives, where they should permanently reside, and not ancient churches, crumbling town halls, or mouldy basements. Harvey was leery of local acquisitiveness when it came to records, some of which were being purchased by outsiders. He was acutely aware that, for many people, the past was little more than a quarry of exploitable properties to be marketed to the travelling public.

With little choice but to facilitate such exploitation when it was demanded by the government, he did so with maximum rigour; Harvey, for instance, made life a living hell for Will R. Bird, whose folksy if factually challenged renditions of history for the delectation of tourists came in for the full Harvey treatment. In this instance at least, Harvey as the province's de facto official

92 Mary E. Williams, "Presentation of Mr. Ritchie's Manuscripts," n.d. [September 1957], RG 53, vol. 18 (1957), PANS. It is germane to note that Williams considered herself to be the greatgranddaughter of Rev. Norman McLeod, a Presbyterian minister who, defying what he took to be the sinfulness of Nova Scotia, migrated with his trusting followers to New Zealand. 
historian was placed in a supervisory role when it came to presenting history to the public. As for the documents themselves, Harvey hoped to keep them secure and worried fretfully when they seemed not to be. He was reluctant to loan out documents to the likes of d'Entremont and he was leery of amateur genealogists in general, some of whom were coming to acquire a reputation for light fingers. ${ }^{93}$ In the Nova Scotia case, such security concerns had been aroused by the questionable collecting habits of archivist W.C. Milner, widely thought to have made off with many documents from trusting locals, and they were later accentuated by the post-career activities of a federal archivist who in the 1950 s marketed many collectibles to a second-hand book and documents dealer in Ontario. If genealogists often felt they were under the watchful eye of anxious custodial archivists, they had good reason: they were not fully trusted with the treasures they craved.

In addition to their occasional social pretentiousness, implicit challenge to the institution's mnemonic authority, and reputation as security threats, the fourth, and probably decisive, mark against the genealogists was that they took up time better dedicated to other things. The more developed institutions in Massachusetts had sophisticated indexing systems, allowing researchers relatively easy access to data. It was true that by the late 1930s PANS had acquired more sources that could be brought to bear on genealogical inquiries. James S. Martell, Harvey's gifted protégé, gradually developed a catalogue of all the land papers, which when completed in 1938 contained some " 35,000 names of people granted land by the Crown from 1775 to 1845 ." On the basis of that list, Marion Gilroy compiled a list of Loyalists and Land Settlement in Nova Scotia. ${ }^{94}$ Yet using this database was timeconsuming and hardly foolproof. Even if the ancestral prey showed up in such sources, the wider significance of their doing so might remain unclear. ${ }^{95}$

In a small institution, digging through such papers, and the many other tasks generated by genealogical inquiries, could not be delegated to a specialized sub-staff: to a surprising extent, many of them fell onto the desk of Harvey himself (assisted after 1945 by Phyllis Blakeley, who undertook them

93 For a discussion of later debates on this issue, see Redmann, "Archivists and Genealogists," 124-5.

94 Marion Gilroy, comp., under the direction of D.C. Harvey, Loyalists and Land Settlement in Nova Scotia (Halifax: Public Archives of Nova Scotia, 1938).

95 Over time PANS assembled an ambitious card catalogue of files on "Biography" and "Places" based on books, manuscripts, and newspapers - records that were, in Ruth Blake's words, of "vast assistance to genealogists and those writing histories of their communities"; see Ruth Blake, "The Public Archives of Nova Scotia" (draft copy, annotated by Phyllis Blakeley, unpublished, n.d. [c. 1955]), Phyllis Blakeley Fonds, MG1, vol. 3090, no. 7, PANS. 
with only slightly more enthusiasm than her boss). When Lovat Dickson of MacMillan and Company of London announced his quest for his ancestors in Truro - "I realise this is not a simple task," he added, with considerable understatement, considering he had only a couple of names to work with an aggressive research campaign was launched on his behalf in Halifax even though, as Harvey stated plainly, "we are not equipped for genealogical work." Harvey sent him three detailed pages of notes, based on PANS land grants, published reports from the United States and Ontario, and Eaton's and Thomas Miller's genealogical work on Kings and Colchester counties. He also made arrangements to receive the esteemed Briton in Nova Scotia in December. In recompense for what must have been many dozens of hours of labour, Harvey suggested a payment of $£ 1$ might be in order. ${ }^{96}$ Possibly Harvey put himself out for a fellow Rhodes Scholar, and possibly he was as always keen to win influential friends for his cash-strapped institution; but the episode also suggests how much even the genealogically-averse Harvey might find himself swimming in genealogical waters as the century progressed.

Similarly arduous was his work in response to a genealogical inquiry from Frederick W. Patten of Melrose, Mass. Harvey was able to locate a Mark Patton on a list of settlers between the river Musquash and Aulac and in a 1770 census return of Cumberland Township. James Martell, also set to chase after Pattons, found none in an "all day search, going through all the files of land grants," but did come up with a draft grant in 1819 to a William Patten who had settled between River Philip and Pugwash. After all of this research work, undertaken for free by PANS and its staff, Harvey did feel that Mr. Patten should pay for any further extensive copying: "We really have no staff here for genealogical researches and I do not feel that we should do this extensively free of charge." 97 When Harvey complained he had been besieged "by correspondents from Boston to San Francisco (including all states of the Union and not omitting Salt Lake City) for information as to grandfathers who came to some part of U.S.," it was the cri de coeur of a man who felt personally overwhelmed by proponents of a form of history he did not really support. ${ }^{98}$

96 Lovat Dickson to D.C. Harvey, 29 August 1951 and Harvey to Dickson, 5 September 1951, 19 October 1951, RG 53, vol. 14 (1950), PANS.

97 Frederick W. Patten to D.C. Harvey, n.d. [November 1936] and Harvey to Patten, 12, 18 November 1936, RG 53, vol. 6 (1936), PANS.

98 T.A. Pugsley to D.C. Harvey, 23 July 1953; Harvey to Pugsley, 7 August 1953; and D.C. Harvey (notes for lecture), "Some Questions Frequently Asked Me," all in Harvey Fonds, MG1, vol. 445, PANS. 
Yet his reservations about genealogy went deeper than his complaints about the countless hours of labour he and his staff members were condemned to devote to it. His deep-seated reservations about genealogy as a form of historical knowledge can be traced back to the 1920s, when he outlined in point form what appears to be a developmental chart for the "Evolution of the Canadian Historian." The first steps were local: family genealogy, "local men \& history," and "national patriotism." The next steps were more ambitious: "orientation" with "motives and policies," as a result of which the peculiarities of Canada's experience of the "Expansion of Europe \& America" would become plain. Thus "the Canadian finds he has a contribution to make to the world view point from his own experience reacting upon his knowledge of the world." Inspired by the "new histories" of the 1920s, Harvey thought he had found a way of combining Canadian history with the histories of humankind; in the margin, he wrote: "There is an idea here if I can work it out." ${ }^{99}$ In this vision, genealogy was not rejected, but it was considered only a first step in a much more expansive and rigorous process of historical discovery.

Much of Harvey's ambition to write a new kind of local history - one that connected the local, the national, and the international - survived his return to Nova Scotia in 1931. In his almost reverential correspondence with Eaton, in which he told the esteemed American that he had hesitated before writing to him because "a private hesitates to approach a general," Harvey quietly dissented from Eaton's vision of how a synthetic history of Nova Scotia might eventuate. Rather than arriving as the culmination of a county-bycounty process of genealogically inclined local histories - i.e., Eaton's Kings County writ large - such a synthetic history would emerge through a dialectic of the particular and the general. In the foreseeable future "general histories and local histories will be a mild check on one another making possible an ultimate, accurate and fairly complete general history." County histories, he complained, "tend too much to the genealogy and the general histories have hitherto featured with 'damnable iteration' certain limited movements and have neglected social and economic, agricultural and educational phases of history." ${ }^{100}$ When Harvey in his annual report of 1940 outlined the three major goals of the archives, they were "the collection and preservation of public and

99 D.C. Harvey, "The French Regime in Prince Edward Island" (typescript), Harvey Fonds, MC1, vol. 465, PANS. See also D.C. Harvey, draft of "Canadian Historians and Present Tendencies in Historical Writing," n.d., Harvey Fonds, MC1, vol. 441, file 94, pp. 4-5, PANS.

100 D.C. Harvey to A.W.H. Eaton, 15 October 1931, RG53, vol. 2 (1931), PANS. 
private documents," the "use of this collection as a bureau of information and an historical laboratory for students," and "ultimately the publication of a comprehensive history of N.S. in several volumes." Genealogy was not even mentioned. ${ }^{101}$

Harvey's moral and intellectual resistance to genealogy, although deeply felt and sometimes eloquently communicated, was frequently expressed in muted, rather passive-aggressive ways. In his capacity as a member of the Historic Sites and Monuments Board of Canada, he had no compunction about asking genealogical historians for advice. ${ }^{102}$ Moreover, Harvey was a public servant, and his Archives answered, directly or indirectly, to politicians. It would have been injudicious, and out of character, for Harvey to refuse genealogical requests from such eminences. Former Prime Minister Robert L. Borden had sounded an alarm about the missing township books of the New England settlers (his uncle, the town clerk of Horton, had once possessed minutes from the "earliest days.") The Archives launched a search for them. ${ }^{103}$ Prime Minister R.B. Bennett, likewise descended from New Englanders, had prevailed upon Harvey to help investigate the perhaps politically valuable although misleading notion that he could also boast of Loyalist ancestors. ${ }^{104}$ Premier Angus L. Macdonald's office was the source of a number of genealogical inquiries. ${ }^{105}$

101 D.C. Harvey, Report of the Board of Trustees of the Public Archives of Nova Scotia for the Year 1940, in Nova Scotia, Journal of the House of Assembly (1941), p6.

102 For example, Judge George Geddie Patterson, son of the legendary Pictou historian George Patterson, and author of Studies in Nova Scotia History (1940) and More Studies in Nova Scotia History (1941), provided Harvey with the genealogy of astronomer Simon Newcomb, who was up for commemoration by the Historic Sites and Monuments Board, and such genealogical data would serve as a check on the "very amusing if vague reminiscences" that surrounded the famous scientist; see George Patterson to D.C. Harvey, 11, 19 March 1935 and Harvey to Patterson, 13, 22 March 1935, RC 53, vol. 5 (1935), PANS. On Patterson Sr., see Allan C. Dunlop, "George Patterson," Dictionary of Canadian Biography 12 (1891-1900), http://www.biographi. $\mathrm{ca} / \mathrm{en} / \mathrm{bio} /$ patterson_george_12E.html. In correspondence with historian W.B. Kerr, who was exploring the question of Nova Scotia's position during the American Revolution, Harvey noted the limitations of the records in both Ottawa and Halifax and confessed that, in the latter case, he "did not know where to turn in order to fill them." So he thought Kerr might usefully rummage through "the New England genealogical registers" to arrive "a more specific estimate as to the actual extent of loyalty or disloyalty in Nova Scotia"; see D.C. Harvey to W.B. Kerr, 6 May 1932, RC 53, vol. 2 (1932), PANS.

103 C.J. Burchell to Alvin F. MacDonald, 1 June 1931; R.L. Borden to C.J. Burchell, 29 May 1931 (copy); A.F. MacDonald to C.J. Burchell, 2 June 1931, RC 53, vol. 2 (1931), PANS.

104 A.R.M. Lower to D.C. Harvey, 24 July 1944 and D.C. Harvey to A.R.M. Lower, 29 July 1944, RG 53, vol. 11 (1944), PANS. In Harvey's view, Bennett's ancestry on both sides was definitely preLoyalist: his paternal forebear was one Benjamin Bennett of Rhode Island, and his maternal ancestor was the presumably pre-Loyalist David Stiles, granted land under the Proclamation of 1763 and hence not a Loyalist.

105 See, for instance, Miriam F. Payzant to J.S. Martell, 23 July 1947, RG 53, vol. 12, PANS. In 1947 Harvey was called upon by the Catholic premier to launch a thorough inquiry, on behalf of one Father Clement Braceland, a priest in Ottawa who thought he was descended from a man who 
Others arrived from a host of town governments, the NSHS, local newspaper editors, and so on. None could be simply cast aside.

On those occasions when he did resist what sometimes seemed to be a genealogical tsunami, Harvey's approach tended to conform to James Scott's notion of "weapons of the weak." ${ }^{106} \mathrm{He}$ might place sotto voce asides in correspondence with people he trusted or assume a tone of haughty aloofness with corresondents he did not know (an approach one aggrieved genealogist nicely characterized as "disinterested, slightly rude"). ${ }^{107}$ Yet sometimes Harvey went beyond that. In October 1947, he was reprimanded by no less a figure than J.C. Webster (1863-1950), a founding father of PANS and the wealthy benefactor of museums at Fort Beauséjour and Saint John, for the "tart reply" he had given an ancestor-hunter researching Loyalist genealogy. "I know how you dislike genealogical investigation," Webster wrote. "So do I." Yet Harvey had annoyed an important person, with potentially damaging results for "the cause of history." In reply, Harvey thought he had been condemned on the basis of second-hand information. It was preposterous to insinuate he would withhold information from a researcher because of an alleged hostility to Loyalists. Yet he did concede that his "very extensive correspondence" with the researcher over the intricacies of Loyalist genealogy and military history had been exasperating:

He persists in expecting me to know about these people when our records yield little or no information, nor can be expected to. I have spent a great deal of time with the assistance of other members of the staff in trying to find anything when I could and I have felt that he took it for granted that we had very little else to do.

As for his supposed coolness towards Loyalists, Harvey said he was merely being a good critical historian. He had only tried to place them "in proper perspective ... and to do this I have found it necessary to criticize a little of

had taught school in Halifax. Harvey considered the priest to have been simply misinformed. Many requests for genealogical information came via the Bureau of Information, a flagship of a tourism industry in which Macdonald had invested much political capital.

106 James Scott, Weapons of the Weak: Everyday Forms of Peasant Resistance (New Haven: Yale University Press, 1987).

107 Lady-May (Mrs. Stewart H.) Giffin of New York City to C. Bruce Fergusson, 22 January 1957, RC 53, vol. 18 (19597), PANS. She does not name Harvey explicitly and was characterizing the tone struck by "officials." 
the blind ancestor worship that has been associated with the Loyalists."108 There was more to Harvey's resistance, it is clear, than just an overworked archivist's anger at being overburdened by genealogical inquiries. The attempt to erect Loyalists into "founding families" - a northern parallel to the reverent ancestor-worship of the more passionate New Englanders - was to be resisted because it was not only fatuously elitist but also factually inaccurate. An historical laborator $y^{109}$ was being asked to fudge its results. As Harvey saw things, he had been forced into a pointless, time-consuming correspondence to help someone construct an essentially dishonest and unbalanced interpretation of regional history.

Such playing with the past had no place in his historical laboratory. In many ways it constituted an affront to Harvey's sense of himself as an historian. If that was the morality of genealogy, Harvey wanted nothing to do with it. "They do not want it to become a center of genealogical research," charged one angry genealogist. ${ }^{110}$ For all his pragmatically necessary compromises and inconsistencies, understandable enough for a man occupying his position and possessed of his moderate political sensibilities, Harvey was nonetheless essentially guilty as charged.

\section{The sorcerer's apprentices?}

After 1945, a new generation of archivists emerged who were far friendlier to genealogy. They believed that the Archives should not only passively accommodate genealogy but also actively encourage it. The easiest way to explain the postwar shift in the institution's stance regarding genealogy might be simply to attribute it to the ascent of C.B. Fergusson (1911-1978), who formally succeeded Harvey as provincial Archivist in 1956. Fergusson, replying to the complaint that the Archives was cool to genealogy, pointed to a number of recent innovations that suggested the situation had changed. Foremost among them was the creation of a Genealogical Committee of the NSHS in late 1952, a

108 J.C. Webster to D.C. Harvey, 1 October 1947, enclosing H.P. Robinson to Webster, 22 September 1947 (copy) and Harvey to Webster, 3 October 1947, RG 53, vol. 12 (1947), PANS.

109 See Carman V. Carroll, "Developing 'an Historical Laboratory': The Genesis of the Public Archives of Nova Scotia," in The Archival Imagination: Essays in Honour of Hugh A. Taylor, ed. Barbara L. Craig (Ottawa: Association of Canadian Archivists, 1992), 178-211. As Carroll notes, in his 25th and final report to the Board of Trustees of the Public Archives of Nova Scotia, Harvey saluted the many historical resources that had been acquired through the years, of which very few "if any can be regarded as alien to an historical laboratory"' (178).

110 Mrs. Stewart Hamilton Giffin of West 24th St., NYC, to Archivist, Archives for Nova Scotia, 3 August 1956, RG 53, vol. 17 (1956), PANS. 
move that Harvey viewed with a distinct lack of enthusiasm. ${ }^{111}$ Whereas Harvey had envisaged a general Nova Scotia history embracing the social, economic, political, and cultural all at once, Fergusson was much more attuned to the accumulation of local biographies as evidenced in his project of assembling a biographical dictionary of all the MLAs of Nova Scotia. ${ }^{112}$

One indication of Fergusson's enthusiasm for genealogical research emerges from his correspondence with S.F. Tucker, who was concerned about commemorating the memory of Rev. George Gillmore (1720-1811). He asked for Fergusson's help in consulting Gillmore's diary, held at Pine Hill Divinity College. Fergusson was able to consult the diary, which PANS held in microfilm, transcribed a good portion of it himself (albeit with some subsequently acknowledged errors), and conferred at length about the aporia and inaccuracies it contained. Tucker felt any words of gratitude would fall short of the priceless service Fergusson had rendered him. ${ }^{113}$ Even a genealogist fierce in her critique of Harvey warmed up to his successor, whom she came to see as a rare example of a "pleasant gentleman"; he was indeed her "ONE BRIGHT LIGHT from NOVA SCOTIA’s Official and Historical and Church Spots." ${ }^{114}$ It was plain to her that a new day was dawning in Nova Scotia.

Whereas Harvey in the 1930s had explicitly discouraged a genealogical orientation for the institution and broadcast far and wide its unsuitability for in-depth genealogical inquiries, Fergusson by 1965 could be found announcing that PANS was the center for genealogical work in the province. Virtually all

111 Phyllis Blakeley to Shirley [Blakeley], 1 November 1951 [with internal letter of 5 November], Phyllis Blakeley fonds, MC1, vol. 3045, PANS. Harvey discouraged Blakeley from joining, although he quickly added: "That is not a command, only a suggestion." For his part, historian Winthrop Bell thought the development might prove "innocuous" at worst and "a useful and interesting addition to the activities of the Historical Society" at best; see Winthrop Bell to C.B. Fergusson, 15 November 1952, C.B. Fergusson fonds, MG1, box 1801, PANS.

112 C.B. Fergusson to L.A. DeWolfe, 3 February 1958, RG 53, vol. 5 (1958), PANS. Fergusson solicited information on "Place of birth; date of birth; name of father; name of mother; name of wife, wife's parents, and place and date of marriage; education; occupation, residence, religious denomination, and date and place of death." It is telling that he placed so little emphasis on political affiliation or ideological orientation.

113 S.F. Tucker to C.B. Fergusson, 30 April, 4, 7 May 1959; Fergusson to Tucker, 8 May 1959; Tucker to Fergusson, 18 May 1959; Fergusson to Tucker, 20 May 1959, Tucker to Fergusson, 28 May 1959; Fergusson to Tucker, 16 June 1959; and Tucker to Fergusson, 19 June 1959, RG 53, vol. 20 (1959), PANS.

114 Mrs. Stewart Hamilton Giffin to Archivist, 3 August 1956; C.B. Fergusson to Giffin, 23 August, 6 September 1956; Ciffin to Fergusson, 23 August 1956, 8 November 1956, RC 53, vol. 17 (1956), PANS as well as Lady-May (Mrs. Stewart H.) Giffin to C.B. Fergusson, 22 January 1957; Giffin to Will R. Bird, 31 January 1957; Giffin to C.B. Fergusson, 22 January 1957; and Fergusson to Giffin, 29 January 1957, RC 53, vol. 18 (1957), PANS. Whether this adulation survived Fergusson's correction of some of Giffin's more egregious historical errors is unclear. Fergusson sought to correct Giffin's impression that Cornwallis's settlers had been returned by the government to England. 
replies to inquiries on genealogical questions emanated from the Archives, he wrote, because it brought together information from so many scattered sources. ${ }^{115}$ Under his guidance, the Archives strove to offer authentic details in response to even the most obscure requests. Oftentimes Fergusson did such work himself, seemingly with enthusiasm. ${ }^{116} \mathrm{He}$ even seems to have passed on unsolicited genealogical tit-bits to eminent people. ${ }^{117}$ Perhaps the acme of the new regime was the issuance in 1967 of the pamphlet Tracing Your Ancestors in Nova Scotia, Nova Scotia's own contribution to a swelling tide of genealogical manuals. ${ }^{118}$ Harvey had died the year before - which was, perhaps, a blessing. This was not his vision of the true vocation of his beloved institution.

The burden of addressing the queries of genealogists fell mainly onto the shoulders of assistant archivist Phyllis Blakeley, who soon wearied of the importunities of Americans ignorant of the most basic procedures of historical research. Blakeley liked to tell of one such inquirer, one Barclay S. Hayes of Arlington, Mass.:

Gentlemen: I am trying to trace my ancestry but have not progressed very far. How did the Hayes family and when did they arrive in Nova Scotia, And from where? England? Scotland? Ireland? or the United States? I have reason to presume they came from Windsor Conn but there is no record of this... My father was born in Round Hill Nova Scotia Harry Statern Bailey Hayes 1876. Who was my grandfather, great grandfather, great-great grandfather? What year did they arrive in Nova Scotia and from where?

115 C.B. Fergusson to Harold Logan, 16 March 1965, RC 53, vol. 27 (1965), PANS.

116 For example, Alberta C. Trimble had heard a rumour that one Ransford Dosworth Bucknam, born at either Hantsport or Hall's Harbor, perhaps in the 1860s, had served in the Turkish navy under the title of Pasha. She was now in search of authentic information [her emphasis]. Fergusson responded with a longish letter with three long and obscure references; see Alberta C. Trimble to Archives, n.d. [April 1965] and C.B. Fergusson to Trimble, 13 April 1965, RG 53, vol. 27 (1965), PANS.

117 Fergusson reached out to former premier E.N. Rhodes, then living in Ottawa, who was pleased to receive data about his grandfather Nelson, whose carpentering career in Boston was a prelude to his entrepreneurship at the carriage works of Rhodes and Curry in Amherst; see C. Bruce Fergusson to E.N. Rhodes, 30 September 1966 and E.N. Rhodes to Fergusson, 5 October 1966, RG 53, vol. 29 (1966), PANS.

118 W.K. Lamb to C.B. Fergusson, 25 July 1967 and Fergusson to Lamb, 27 July 1967, RG 53, vol. 23 (1967), PANS. Dominion Archivist W. Kaye Lamb thought the title was highly reminiscent in title of his own institution's Tracing Your Ancestors in Canada, although Fergusson noted that both pamphlets had been strongly influenced by a prior text: Trace Your Ancestors by L.C. Pine (London: Evans Brothers, 1954). For the contemporary version of Tracing Your Ancestors, see https://www.collectionscanada.gc.ca/obj/022/f2/022-607.001-e.pdf. 
“They always expect a miracle," Blakeley grumbled, "How should I know?"119 Will R. Bird, the impresario of much of the province's fledging field of historical tourism, steered one visitor to the Archives with the terse instruction to "look after the ancestors of this lady or tell her they are not listed." His impatience was perhaps not wholly unwarranted: the visitor wanted birth, death, marriage, and other family information about a minimum of three people (and perhaps many more once the extended family was taken into account), only some of whom were known to have been in Nova Scotia. ${ }^{120}$

Other ancestor-hunters arrived with colourful family stories they hoped might be confirmed in Nova Scotia. For Mrs. D.S. Baker, writing from New Hampshire, the object of her quest was to establish that her newly born granddaughter, Wendy Valentine, was the seventh generation to bear the name Valentine. ${ }^{121}$ Stuart D. Hyle wanted local confirmation of family tales of a piratical background: "After all, it isn't every day that one finds out his ancestors were pirates and cut-throats." ${ }^{122}$ What general insight into history would be generated if that turned out to be the case - or didn't? Or is any such questioning out-of-place in a new consumer-driven dispensation, in which history is primarily a source of entertainment?

After the 1940s it became painfully evident that one was often no longer dealing with polished literary genealogists of the Eaton sort but rather rank amateurs, many of them from the United States. PANS often resembled a "contact zone," a social space (as Mary Louise Pratt explains) where two cultures meet and sometimes clash in a context in which one is endowed with a sense of cultural superiority and the other a resentful sense of being patronized or even exploited. ${ }^{123}$ The attitude of metropolitan superiority assumed by some Americans could rub Nova Scotians the wrong way: "She is what we call a 'white-washed Yankee'," exclaimed Blakeley in 1949 of one particularly difficult American. This visitor was described as "a Nova Scotian who has absorbed all the ignorant ideas current in America and is condescending to everyone who

119 Phyllis Blakeley, untitled note, n.d. [1980s], MG 1, vol. 3090, no. 7, PANS.

120 Mrs. W.M. Prince of Princeville, Oregon, to Will R. Bird, Bureau of Information, Province House, 22 April 1953, RG 53, vol. 15 (1953), PANS.

121 Mrs. D.S. Baker to C.B. Fergusson, 10 October 1966, RG 53, vol. 28 (1966), PANS.

122 Stuart D. Hyle to Head Librarian, Public Library, Halifax, 20 November 1954 (copy) and C.B. Fergusson to Hyle, 23 November 1924, RG 53, vol. 15 (1954), PANS.

123 See Mary Louise Pratt, Imperial Eyes: Travel Writing and Transculturation (London: Routledge, 1992). 
isn't a citizen of the United States, and generally acts as no true American ever would." ${ }^{224}$

Some Americans arrived with an almost belligerent need to settle their minds as to their ethnic origins. Walter G. Burke of Waltham, Mass., born 1892, and evidently not a man of the social elite, was keen in 1956 to settle for once and for all whether he was of French or Irish descent: "Any where I went I have always been taken for irish descent. I must have proof before I change it." He seemed to be saying that, if worst came to worst, he would have to own up to being of French descent, but only if presented with irrefutable evidence. The Archives returned what was likely to him a discouraging response: his roots undoubtedly lay in francophone Minudie. But Burke seized on the phrase "there is some doubt about it" to respond with his own version of the truth, in which he imagined his supposedly Irish forebears crossing the Atlantic, settling for a time in Newfoundland, and then wresting "a living from the soil." The archivist obligingly came up with two land-seeking Irish carpenters who might fit the bill, albeit with the significant proviso that he had been "unable to connect these individuals with your ancestry."125

Other Americans arrived fired with a sense of the absolute urgency of their familial researches, which they expected Nova Scotians in general to share. The 1957 visit of Mrs. Stewart H. (Lady-May) Giffin of New York City presents us with an illustration of some of the conflicts that might then arise in a genealogical contact zone. This category (3) genealogist charged that upper crust Haligonians were content with slipshod research and outright falsehoods. Here was a courageous researcher who, in her own mind, had defied them with her genealogical truths - "the facts, and not the Bunk!" - and, in consequence, received rude mail from ignorant Nova Scotians: "I get such charming letters, like: 'No ignorant stranger is going to tell me my ancestry, my ancestor came with Cornwallis, English, etc. and New Englanders came here 1760 . .."' ${ }^{126}$ Assuming the stance of a tough-minded empiricist confronting know-nothings contented with "Traditions" or "Wishful Thinking," she proclaimed it was foolish to "retain Fairy tales, once one's learned the facts." ${ }^{127}$ Upon learning,

\footnotetext{
124 Phyllis Blakeley to Uncle Welton and Aunt Annie, 27 October 1949, from 46 Westmount Street, Halifax [with internal letters of 28, 29 October, 1, 2, 3, 4 November, 1949], Phyllis Blakeley fonds, MC 1, vol. 3045, PANS.

125 Walter C. Burke to Will R. Bird, 16 September 1956; C.B. Fergusson to Bird, 25 September 1956; Burke to Fergusson, 1 July 1958; and Fergusson to Burke, 10 July 1958, RG 53, vol. 19 (1858), PANS

126 Lady-May (Mrs. Stewart H.) Giffin of New York City to C.B. Fergusson, 22 January 1957, RC 53, vol. 18 (1957), PANS.

127 Mrs. Stewart H. Giffin to Will R. Bird, 31 January 1957, RC 53, vol. 18 (1957), PANS.
} 
evidently from an American newspaper, ${ }^{128}$ that the Archives had acquired the collection of a prodigious genealogical researcher in Queens County, T.B. Smith, Mrs. Giffin feared for its safety in an institution run by incompetents. So headstrong were members of the Halifax elite, not to mention the leaders of the Giffin Family Association with whom she was also locked in battle, that they might even be tempted to tamper with the primary source itself. ${ }^{129}$

Despite such misgivings, Giffin issued a long list of tasks for the Archivist, along with an enclosed form for him to complete and "return at once."130 When the archivist dutifully responded, she fired off an even angrier missive that advised him that he had only given her a rehash of Smith's (and her own) findings. "I realize, you are not delighted at even hearing from me," she wrote him in November 1956 (that was perhaps an understatement). She went on to mock, with a deadly accuracy, the officious tone of the institution's correspondence: "While letters are acknowledged - that is almost all: 'We've noted what you said, or noted what you sent to us'." Rising to a crescendo, she demanded her genealogical inquiries be answered, satisfactorily and promptly: "May I this once, beg of you, to bear with me $-\&$ answer the previous 8 questions ...."."

As Mrs. Giffin's tone suggested, some genealogists arrived convinced that their research missions were of momentous importance. Mrs. S.W. Dickie of North Haven, Connecticut, writing well in advance of her visit in August 1956, set the Archives to work on her behalf. Like many genealogists, she emphasized that much depended on her speedily finding answers to her queries. "Please don't question my motives in this," she cried. She confessed she was on "a treadmill of curiosity and the more I learn the more I realize I must know." The entire story of the North Carolina Regiment that had arrived in Nova Scotia and settled near Country Harbour needed to be written: "There is a book there are many books - to be written of this fabulous but neglected phase of history. I would love to do it but feel that I am not capable." ${ }^{132}$ Yet after such

128 Winthrop Bell to C.B. Fergusson, 15 August 1956, C.B. Fergusson fonds, MG1, box 1801, PANS.

129 As detailed in note 55, Smith's genealogical data was such that, in his estimation, he had researched about 15 per cent of all the people who had lived in Queens County. See T. Brenton Smith to C.B. Fergusson, 19 November 1953 and Smith to Fergusson, 30 November 1953, RC53, vol. 15 (1953), PANS as well as Mrs. Stewart Hamilton Giffin to Archivist of Nova Scotia, 8 November 1956, RG 53, vol. 17 (1956), PANS.

130 Mrs. Stewart Hamilton Ciffin of West 24th St., NYC, to Archivist, Archives for Nova Scotia, 3 August 1956 (emphasis in original), RG 53, vol. 17 (1956), PANS.

131 Mrs. Stewart Hamilton Giffin of West 24th St., NYC, to Archivist, Archives for Nova Scotia, 8 November 1956 RG 53, vol. 17 (1956), PANS.

132 Mrs. S.W. Dickie to D.C. Harvey, 14 July 1956, RG 53, vol. 17 (1956), PANS. 
expressions of urgency, she did not visit the Archives when first she reached Halifax. "My children have no patience with my obsession with the Loyalists," she lamely explained. She took her family to Country Harbour, before it became too dark. Returning to Halifax, she once again stood the Archivist up. Nonetheless, unfazed, she then presented him with a list of demands:

There is one thing I want right now, though, and that is a map of the original land grants, to whom they were granted, the muster rolls of the three regiments, where the migration from Sherbrooke took the inhabitants, namely Dickie (to Guysborough?), and any reference at all to the origin of Modstock. This name is spelled "Modistock" in the Country Harbor cemetery. I do not remember the spelling on your map, but as there is a story in our family that he was a Russian, I cannot help but think that this idea comes from the fact that one name I have run across in "Marriage Notices" and "Death Notices" in the "South Carolina Gazette" from 1766 to 1781 is "Mazyck." . . Now on still another matter.... ${ }^{133}$

Slowly, a province not hitherto much attuned to genealogical ways was brought into contact with outsiders whose perceptions of the past were shaped by them. As early as the late 1950 in Nova Scotia, genealogy became a sufficiently remunerative trade that one might venture to make it a full-time profession (as it had been in the northeastern US since before the 1880s). ${ }^{134}$ Such emerging category (5) professionals had new resources upon which to draw the Mormons, striving to fulfil their mission to baptise by proxy the departed as well as the living, started their program of the mass diffusion of genealogical resources on microfilm. ${ }^{135}$ By the 1970 and 1980s, the Archives had much more to offer genealogists: thousands of "biography" cards (many of them the work

133 D.C. Harvey to Mrs. S.W. Dickie, 31 August 1956; Dickie to Harvey, 17 September 1956; and Phyllis Blakeley to Mrs. S.W. Dickie, 27 September 1956, RG 53, vol. 17 (1956), PANS.

134 By 1957, one could consult Margarita Wallace, who charged two dollars per hour (or a set fee) for her services in "Cenealogical and Historical Research" and "Free Lance Writing." And in 1958, Miss Muriel Edwards was also mentioned as a possibility for people looking for genealogical researchers. See Rate Card for Margarita Wallace, RG 53, vol. 18 (1957), PANS as well as C. Bruce Fergusson to John A. MacLean, 11 March 1958, RG 53, vol. 19 (1958), PANS. By contrast, Harvey in 1933 said he knew of no one in Nova Scotia who might undertake genealogical research for the American Historical Society; see D.C. Harvey to M.M. Lewis, 29 December 1933, RG 53, vol. 5 (1933), PANS.

135 C. Bruce Fergusson responded to a request from the premier's office to confirm receipt of an agreement with the Mormons in September 1967; see C.B. Fergusson to Innis G. MacLeod, 1 September 1967, RG 53, vol. 20 (1967), PANS. 
of Blakeley) based on newspaper and other evidence offering insights into particular individuals as well as case upon case of microfilmed church records and past genealogical researches. Ultimately, in the new building of the 1980s, there was an entire room of microfilm readers destined primarily for their use.

The demographic characteristics of the genealogically inclined public changed as well. The percentage of Canadian "visits" to the institution rose markedly, while that of the Americans and New Englanders dropped just as precipitously. ${ }^{136}$ Blakeley, reminiscing in the 1980 os, wrote that the 1960 s put her in mind of Walt Disney's Sorcerer's Apprentice (1940) in that, like the poor broom-wielding apprentice, she felt overcome by a "rising tide of general researchers, M.A.'s and professors, school tours, genealogists and tourists, community historians, journalists and T.V. writers," all in large measure activated by the celebration of Canada's Centennial in 1967. ${ }^{137}$ The era of the "patriotic Nova Scotian" resident in New England was drawing to a close while that of the "patriotic Canadian" investigating his or her "roots" in Nova Scotia was in full bloom. The popularity of the television show with that name in 1976 made genealogy seem an important enterprise in establishing one's identity; Harvey would not have found it reassuring to learn how frail was much of the factual foundation of Roots. ${ }^{138}$

In retrospect the rise of mass genealogy in the 1960s and 1970s can be represented Whiggishly as a democratic breakthrough. and in a sense one can see the logic of the argument. If a decided aroma of patrician elitism hangs over the literary musings of Eaton and the fantasies of Blanchard, today's "genealogist" - category (1) may be just about anyone who can purchase an account with ancestry.com. Today's category (5) professional genealogy community, meanwhile, has fully professionalized, with an elaborate apparatus of methods, journals, and even arcane theoretical debates. So it is that, in some interpretations, we have travelled from an "exclusive, class- and race-based

136 Overall, the percentage of American visits decreased from about 34 per cent in 1935 to about 6 per cent in 1960-1964; see Visitors Registers, PANS (in possession of author).

137 Phyllis Blakeley, "Forty Years at the Archives" (4 April 1986); see MG1, vol. 3124, PANS. For an illuminating study of the popular response to Nova Scotians to the Centennial, see Meaghan Elizabeth Beaton, The Centennial Cure: Commemoration, Identity, and Cultural Capital in Nova Scotia during Canada's 1967 Centennial Celebrations (Toronto: University of Toronto Press, 2017). See also Neal Gabler, "Disney's 'Fantasia' Was Initially a Critical and Box-Office Failure," https:// www.smithsonianmag.com/arts-culture/disney-fantasia-critical-box-office-failure-180956963/.

138 See Jennifer Keishin Armstrong, "Roots: The Most Important TV Show Ever?" 2 June 2016, http:// www.bbc.com/culture/story/20160602-roots-the-most-important-tv-show-ever. 
cultural activity and means for self-assertion" into a sun-lit land in which genealogy has become "a democratic and multicultural pursuit." 139

But might not Harvey's critique of genealogy caution us against too rapturous embrace of this new, improved, and decidedly corporate version of the old form of inquiry that so roused his suspicions? Harvey might rightly find the new regime of market-driven genealogy to be an implicitly irrationalist one because it replaces any concern for processes of social and political evolution with an individualist accumulation of untheorized personal details. If for \$21.99 per month one evidently can purchase history as a personal commodity, what need is there to inquire into the structures and processes generating the disaggregated data arriving in one's in-box? What will one learn about the evolution of the social order and the structures of government by learning, on the basis of supposedly scientific evidence, that one is 35 per cent Scottish, 45 per cent Ukrainian, and 20 per cent "Something Else"? The epoch of the category (5) genealogist is upon us, and it now offers its customers not only heartening stories but pie-charts and algorithms - all seemingly offering support to atavistic and biologically determinist readings of human history.

What Harvey sought - an integrated, coherent, and factually accountable version of the past through which his fellow citizens might acquire a better understanding of their mutual obligations as well as their rights - seems more distant than ever. And this applies even more to his objection to the time and labour constituted by genealogical inquiries, especially since this is an era when so many other important realms of provincial experience want for historians. As he readily conceded, genealogical inquiries might play a useful subordinate role in rigorous historical inquiry. If, on the other hand, they were imagined to be decisive influences on the core methodology and overarching interpretation of that inquiry or shaped the critical insights that that inquiry might inspire, they would constitute something like a moral threat to the historian's scientific enterprise. If few would counsel the 21st century re-adoption of his optimistic liberal narrative, which made so little room for Indigenous peoples, racialized minorities, and the working class, more might ponder whether purchasing imagined histories of noteworthy individuals offers much of an improvement on it. Perhaps it is merely a perpetuation of the settler-colonial imperatives that have structured the genealogical enterprise in North America from its beginnings? 
IAN MCKAY est le directeur du Wilson Institute for Canadian History à l'Université McMaster. Il travaille présentement à la rédaction d'un historique des Archives publiques de la NouvelleÉcosse. Sa dernière publication, écrite en collaboration avec Peter Graham, est Radical Ambition: The New Left in Toronto (Toronto, Between the Lines, 2019).

IAN MCKAY is the director of the Wilson Institute for Canadian History at McMaster University. He is working on a history of the Public Archives of Nova Scotia, and his last publication, with Peter Graham, is Radical Ambition: The New Left in Toronto (Toronto: Between the Lines, 2019). 